Published in: Journal of Quaternary Science, vol 27, issue 4, pages 371-

382.

https://doi.org/10.1002/jqs.1555

5

\title{
Sensitivity of the Eastern Mediterranean geomorphic system towards environmental change during the Late Holocene: a chronological perspective
}

Bert Dusar $^{\text {a,* }}$, Gert Verstraeten ${ }^{\text {a,b }}$, Koen D’Haen ${ }^{\text {a }, ~ J o h a n ~ B a k k e r ~}{ }^{\text {a,b }}$, Eva Kaptijn ${ }^{\mathrm{c}}$, Marc Waelkens ${ }^{\text {b,c }}$

${ }^{a}$ Geography Research Group, Department of Earth and Environmental Sciences, Katholieke Universiteit Leuven, Celestijnenlaan 200E, box 2409, 3001 Leuven, Belgium

${ }^{\mathrm{b}}$ Center for Archaeological Sciences, Katholieke Universiteit Leuven, Celestijnenlaan 200E, box 2408, 3001 Heverlee, Belgium

${ }^{c}$ Archaeology Research Unit, Katholieke Universiteit Leuven, Blijde Inkomststraat 21, 3000 Leuven, Belgium

* Corresponding author. Tel. +32 163224 29. Fax. +32 1632 29 80. Email: bert.dusar@ees.kuleuven.be
Abstract
Alluvial and colluvial sediment deposition form a vital record of environmental change during the Holocene. Firm chronological control on these archives is necessary to enable us to relate sediment dynamics to human activity and climate variability. In the Eastern Mediterranean, such relationships are hard to establish due to the lack of spatially well distributed sediment archives with good chronological control. This scarcity is problematic with respect to regional-scale reconstructions of the temporal variation of sediment dynamics. Here, we present a radiocarbon database $(n=178)$ of geomorphologic activity collected from multiple distinct sediment archives within the territory of Sagalassos in south-western Turkey. The data were grouped according to their sedimentary facies for analysis using cumulative 
probability distributions (CPD) and sedimentation rate (SR) modelling. Two small-scale colluvial valleys, where chronological information was abundant, were investigated in more detail.

Results show that sedimentation chronology differs between individual, nearby cores, since it strongly depends on the local geomorphic situation. A generalizing approach combining multiple cores' results yields more widely valid conclusions. High sedimentation rates coincided with the initial major anthropogenic disturbance of the landscape and decreased afterwards, probably due to hillslope soil depletion. CPD and SR analysis indicates that generally colluvial sedimentation rates did not change much from $2000 \mathrm{BC}$ onwards. River floodplain sedimentation, in contrast, increased markedly during the first millennium BC and during recent times and a significant time lag in enhanced sediment deposition between the upper and lower reaches of the river valleys was observed.

Keywords: radiocarbon dating, sedimentation rates, geomorphic activity, Sagalassos, Turkey, cumulative probability distributions

\section{Introduction}

Ancient soil erosion has received considerable attention within the scientific community (e.g. Montgomery, 2007). Past civilizations have modified the landscape through agriculture, logging and grazing, while climate variations also have had a significant impact. As is the case nowadays, humans have consistently attempted to contain sediment dynamics by building e.g. terraces and check dams (e.g. Van Andel et al., 1990). In the Eastern Mediterranean, many studies have studied sediment archives in order to assess landscape changes from both a qualitative and quantitative standpoint. Moreover, these studies have investigated the geomorphic system from small scale colluvial deposits (e.g. Fuchs et al., 2004) up to large river catchments and coastal deltas (e.g. Brückner et al., 2006). Results have been compared to other palaeo-environmental information, both on a small scale (e.g. Lespez, 2003) and on a regional scale (Dusar et al., 2011). However, every palaeo-environmental study relies heavily on temporal information to establish relationships between e.g. land use changes and changes in sediment archives.

60

Therefore, firm chronological control on past environmental change is critical for palaeoenvironmental research, also in the Eastern Mediterranean region. Archaeological investigations mostly rely on cultural indicators such as ceramics for dating, while for the reconstruction of the past landscape sediment archives are a valuable data source. From 
sediment archives in the Eastern Mediterranean, chronologies of past environmental change have been reconstructed, but these are mostly limited to specific locations (e.g. Gölhisar Gölü, Turkey: Eastwood et al., 1999; Drama basin, Greece: Lespez, 2003; Phlious basin, Greece: Fuchs, 2007; Kinet Höyük, Turkey: Beach and Luzzadder-Beach, 2008; regional overview: Dusar et al., 2011). These studies illustrate the large spatial variability in the chronology of 70 geomorphic processes in the region, probably due to the influence of local factors. An integration of these small-scale investigations into a region-wide analysis of the temporal variation of geomorphic process intensity has only recently been presented (Dusar et al., 2011). However, to properly relate geomorphic process intensity to other palaeoenvironmental variables such as vegetation, climate and human activity, chronological information concerning the entire geomorphic system must be integrated.

Several studies have integrated chronological data concerning the geomorphic system at a regional scale in Western and Central Europe (e.g. Lewin et al., 2005; Macklin et al., 2006; Hoffmann et al., 2008; Macklin et al., 2010; Turner et al., 2010; Notebaert et al., 2011a), in 80 the Western Mediterranean (Thorndycraft and Benito, 2006a), India (Kale, 2007), North Africa (Zielhofer and Faust, 2008), and in south-western USA (Harden et al., 2010). Previously developed techniques to establish site specific chronologies and analysis tools for large chronological databases were applied. The spatial integration of temporal information for colluvial deposits in Germany allowed for the reconstruction of the so-called sediment pathway, which was described as a cascade model with several temporary, intermediate sediment sinks (Lang and Hönscheidt, 1999). Moreover, reliable chronologies were reconstructed for small river basins by combining both radiocarbon and luminescence dating (e.g. Lang and Nolte, 1999). In order attain to a regional scale analysis, dating information from several individual locations can be integrated by summing the age probabilities of obtained chronometric data (Lang, 2003; Lang et al., 2003; Thorndycraft and Benito, 2006b). Recently, this method was further refined by grouping the obtained data according to their geomorphic situation (Macklin et al., 2010; Turner et al., 2010), and by attempts to take the influence of the shape of the radiocarbon calibration curve and preservation potential into account (Hoffmann et al., 2008; 2009; Notebaert et al., 2011a). Cumulative probability distribution and age-depth analysis, as well as floodplain sediment storage quantification for different parts of the large-scale Rhine river catchment enabled to establish the importance of past human impact, primarily through land use change, on the geomorphic system at this scale (Hoffmann et al., 2009). Thorndycraft and Benito (2006b) established a fluvial chronology of 
Spain and the links with driving forces by applying the same techniques. However, the validity of some analysis techniques applied over the last few years is a matter of ongoing discussion (Chiverrell et al., 2011a; Macklin et al., 2011; Chiverrell et al., 2011b).

In the Eastern Mediterranean only few landscape scale chronologies have been established. Some studies have dated the formation of alluvial and colluvial fans (e.g. Van Andel et al., 1990), embayment siltation (e.g. Lespez, 2003) or floodplain sedimentation in small river basins (e.g. Casana, 2008). However, most research lacks integration over several spatial scales or morphologic processes, and chronologies differ strongly over the region (Bintliff, 2002; Dusar et al., 2011). Most scholars rely on limited data to establish a chronology of geomorphic activity, which hampers the interpretation and link with the driving factors of

110 landscape change. The limited availability of organic material, a major issue in Western Europe (Lang and Nolte, 1999), is even more problematic in the Mediterranean, since the region's climate is even more unfavourable to preserve ancient organic matter. A firm chronology of past geomorphic processes in the region can be obtained, however, by integrating chronological information from various archives along the sediment redistribution 115 pathway.

The aim of this study is to investigate the temporal variation in geomorphic system response to environmental change during the late Holocene in the territory of Sagalassos, a HellenisticRoman city in the Taurus mountain range in south-western Turkey (Waelkens et al., 1999).

120 Over the last two decennia, several case studies have investigated the local history of several aspects of the geomorphic system in the region (Kaniewski et al., 2007a; Six et al., 2008). Here, a database of all available radiocarbon data $(n=178)$ was analyzed to study the chronology of geomorphic activity on a regional scale and to assess the importance of various geomorphic processes. First, an investigation and comparison of two small endorheic basins can clarify the importance of local factors and small-scale spatial variability in sediment dynamics. Second, a regional analysis of the spatial variability of sedimentation rates can inform us about the timing of the principal periods of geomorphic activity across multiple spatial scales. Using a scale dependent approach and by distinguishing between colluvial and alluvial deposits, time lags in the response of the geomorphic system to changes in driving 130 forces can be detected. These driving forces, primarily land cover and climate change, have been studied extensively in the study area (Kaniewski et al., 2007a; 2007b; 2008; Bakker et 
al., submitted a and b; Dusar et al., 2011). This allows us to thoroughly compare the geomorphic system chronologies with the palaeo-environmental record.

\section{Study area}

This paper concerns the $1000 \mathrm{~km}^{2}$ territory of antique site of Sagalassos in southwest Turkey (Fig. 1). The topography of the territory ranges from Burdur Lake (850 $\mathrm{m}$ a.s.l.) to the summits of the Beşparmak mountains (2000 m a.s.1.) in the west and from the Aksu valley (650 $\mathrm{m}$ a.s.1.) to the summit of the Akdağ Mountain (2250 $\mathrm{m}$ a.s.1.) in the east. The main river systems are the Büğdüz River in the west and the Ağlasun River in the east. The geological setting of the territory of Sagalassos is complex, since it is situated at the north-western apex of the Isparta angle and at the north-eastern extremity of the Fethiye-Burdur fault zone (Verhaert et al., 2006). The autochthonous Bey Dağları massif has been overthrusted from the east by the Antalya nappes during the Late Cretaceous and Paleocene (65-56.5 Ma), and from

145 the northwest by the Lycian nappes during Late Miocene times (11.6-5.3 Ma) (Glover and Robinson, 1998). Dominating lithologies are limestone (27\%), marls (24\%) and ophiolitic mélange (12\%), as well as extensive quaternary deposits on the valley floors. Palaeo-environmental research within the Sagalassos project has focussed on several distinct research goals; therefore, sediment archives have been studied in various geomorphic situations. Initially, the hillslopes neighbouring the archaeological excavation site of Sagalassos were studied (Six et al., 2008), as well as the nearby Ağlasun Çayı valley (Fig. 1; Six et al., 2008). Later, the Gravgaz intramontane basin (Fig. 1) became a major focus, since the marsh in its valley bottom allowed for the combination of geomorphologic research with palynological investigation and the reconstruction of past land use (Six et al., 2008; Vermoere et al., 2000, 2002). Recently, the Büğdüz river system in the west of the Sagalassos territory was studied (Fig. 1), in order to study the Holocene changes of the Eastern Mediterranean geomorphic system on a larger scale, and to quantify sediment fluxes. The relatively flatbottom, low gradient and wide valley upstream reaches of the Büğgüz river system differ markedly from the lower reaches, which are characterized by an incised river channel and significant height differences within the floodplain. In fact, the upstream reaches largely resemble the smaller scale zero-order colluvial valleys lacking a natural drainage system in the area, such as at Gravgaz.

In the Sagalassos territory, human occupation in the form of villages can be traced back to the Chalcolithic period (ca. 6000 BC). However, sites recovered from these early periods are low 
in number and the archaeological periods are of long duration. With the start of the first millennium BC the situation changes (Fig. 2). While the first two centuries remain elusive in the territory of Sagalassos, with the advent of the Archaic period (750 - $550 \mathrm{BC}$ ) several newly founded settlements appear that often continue into the subsequent Classical (550 - 330 BC) and Hellenistic (330 - 25 BC) periods. During these periods settlements were primarily located on easily defendable hilltops with agricultural and grazing lands close by. During the subsequent Roman period (25 BC - 300 AD) and Late Roman-Early Byzantine times (300 700 AD) the settlement number increased, the total settled area expanded and settlements were located primarily on fertile, flat areas (Vanhaverbeke and Waelkens, 2003). Throughout these two periods, agricultural activities were concentrated in the flat, fertile valley bottoms and relatively low-lying hilly areas, while the surrounding hill slopes were used for grazing. It is assumed that pressure on the landscape was at its maximum during the Roman period (25 BC - $700 \mathrm{AD}$ ) in the area (Vanhaverbeke and Waelkens, 2003). During the post-Roman periods the number of sites decreased. Periods marked by sedentary agriculture were alternated by periods for which archaeological evidence of occupation is lacking, and during which nomadic pastoralism was probably the main mode of subsistence.

\section{Methods}

In order to investigate the geomorphic system chronology for the territory of Sagalassos, a database was assembled containing the radiocarbon data $(n=178)$ obtained from all palaeoenvironmental case studies conducted over the last 20 years. 110 of the data were obtained by the authors from the Büğdüz river catchment west of Sagalassos (Fig. 1); 33 were retrieved from the Gravgaz basin (Six et al., 2008; Fig. 1); a further 35 data originate from the eastern part of the territory, primarily from the Ağlasun river catchment (Six et al., 2008; Fig. 1).

Samples for radiocarbon dating were obtained through hand augering, percussion drilling or using a Dachnowski coring device. Selected samples were sieved and organic material was handpicked from the fraction larger than $125 \mu \mathrm{m}$. Only terrestrial plant remains, seeds and wood were selected for dating, in order to avoid the hard water effect (e.g. Moore et al., 1998) and the reservoir effect for non-terrestrial plant remains (e.g. Törnqvist et al., 1992). All radiocarbon data, also those obtained from previously published research, were calibrated using OXCAL 4.1 (Bronk Ramsey, 2001, 2009) and the IntCal09 calibration curve (Reimer et al., 2009). To avoid confusion, all calibrated ages are reported in years (a) BC/AD. 
Additionally, information concerning stratigraphy and geomorphic information was added for each sample contained in the database. Stratigraphical information mainly distinguished between fluvial channel and overbank deposits. Geomorphic information concerned the discrimination between process domains: colluvial versus alluvial deposition. Subsequently, the database was grouped by geomorphic situation and stratigraphical position of the samples.

205 Peat layer samples were separated from detrital sediment samples, since the former may indicate landscape stability or a decoupling between the hillslopes and the sediment archive (e.g. Notebaert et al., 2009). Detrital sediments were further grouped based on their geomorphic situation: colluvial deposition samples were distinguished from upper and lower reach alluvial samples. The alluvial samples were further subdivided into relatively fine overbank deposits samples and coarse channel bed deposits samples.

Recent investigations of chronological databases from western Europe frequently make use of cumulative probability distributions (CPDs), e.g. in Britain (Macklin and Lewin, 2003; Lewin et al., 2005; Macklin et al., 2010), Poland (Starkel et al., 2006), Spain (Thorndycraft and

215 Benito, 2006a, b), Germany (Hoffmann et al., 2008), the Rhine catchment (Hoffmann et al., 2009) and the Belgian Dijle catchment (Notebaert et al., 2011a). The methodological framework was further improved by grouping ages corresponding to active sedimentation phases and normalization of the probability curve to limit the shape effects of the calibration curve, preservation potential and sampling bias (Hoffmann et al., 2008, 2009; Notebaert et al., 2011a).

However, Chiverrell et al. (2011a) strongly doubt the validity of much of the aforementioned cumulative probability distribution analyses. Firstly, Chiverrell et al. (2011a) state that the assumption that each radiocarbon measurement is a true age estimate for a point in time is not valid. Secondly, they argue that much of the CPD structure is related to the shape of the radiocarbon calibration curve. Thirdly, Chiverrell et al. (2011a) claim that temporal relationships between the dated material and the supposedly dated event are not always straightforward, e.g. due to pre- or postdating, giving rise to the integration of variable time lags in the analysis. Finally, they state that chronometric data that were not tested for their robustness, such as from stratigraphies with temporal inversions, should not be included in a CPD analysis (Chiverrell et al., 2011a). These arguments are all valid if the CPD approach is applied to investigate a database of geomorphologic events of relatively short duration, such as floods. For the Sagalassos regional database, we do not aim to establish a very detailed 
chronology, but rather a general picture of geomorphic activity with a centennial-scale resolution (cfr. Macklin et al., 2010). The identification of single events which occurred over the entire landscape is impossible, since the spatial and temporal resolution of the investigated sediment archives is limited. Therefore, the cumulative probability values in the CPD were averaged over 100 year bins, which agrees with a more generalized interpretation of the CPDs. This approach allows to identify the principal periods of geomorphic activity within 240 the study area. This generalization effectively counters the first and third arguments brought forward by Chiverrell et al. (2011a). The second argument, concerning the influence of the shape of the radiocarbon calibration curve on the CPD structure, was already countered by Hoffmann et al. (2008) and Notebaert et al. (2011a). These authors divide the CPD of all radiocarbon data by a CPD of 100 equally spaced radiocarbon ages, in order to eliminate the calibration curve structure. In this paper, the original CPD was divided by a CPD of 1000 equally spaced radiocarbon ages with the average standard deviation of the entire database, namely 45 years. The fourth and final argument by Chiverrell et al. (2011a), concerning the robustness of the radiocarbon data, is partially answered by the generalizing approach discussed above. Stratigraphical inversions indeed yield unreliable chronologies for single sediment archives (Chiverrell et al., 2011a), but each dated stratigraphical layer still represents a period of geomorphic activity, and should therefore be included in the generalized CPD approach. However, in case multiple radiocarbon samples from the same layer were dated and yielded statistically not significant inversions, these data were aggregated to give a more generally valid age datum for that stratigraphical layer. After 255 cleaning up the dataset following this approach, only in 5 out of the 39 available dated cores significant inversions remained.

In this study CPDs were constructed for subgroups (colluvial samples, upper and lower valley alluvial samples) of the Sagalassos radiocarbon database, in order to detect the most significant periods of geomorphic activity. For peat growth, a process limited to one study site in the region (i.e. the Gravgaz basin; $n=16$ ) and therefore not deemed regionally significant, no CPD was constructed. Additionally, the data obtained from coarse alluvial channel bed deposits originated from only two study sites $(n=11)$. Since this undoubtedly important process is poorly dated, these data were not included in the CPD analysis. The CPD of colluvial ( $n=57)$, upper $(n=23)$ and lower valley $(n=30)$ alluvial data were corrected for the influence of the calibration curve by dividing it by the CPD of 1000 equally spaced ages (cfr. Hoffmann et al., 2008) with a standard deviation of 45 a, corresponding to the average 
standard deviation of the entire database. An alternative correction for preservation potential by dividing by the CPD of all available ages (Hoffmann et al., 2008) was not applied, because of the variable preservation potential for the different depositional environments. These differences in preservation potential would lead to an overestimation of the importance of processes with a high preservation potential for a certain period, and vice versa. Finally, the cumulative probabilities were averaged over 100 year bins in order to avoid the interpretation of single peaks as 'events' and to deal with the fact that radiocarbon data are no true age estimates for a point in time (Chiverrell et al., 2011a).

Besides the CPD analysis, the temporal changes in geomorphic response to environmental change can be studied through analysis of sedimentation rates (e.g. Hoffmann et al., 2009; Notebaert et al., 2011a). Sedimentation rates $\left(\mathrm{SR}_{\mathrm{a}}\right)$ are calculated in most studies (e.g. Kaniewski et al., 2007a) for each radiocarbon dated sample i using the following equation:

$$
\mathrm{SR}_{\mathrm{a}, \mathrm{i}}=\left(\mathrm{D}_{\mathrm{i}}-\mathrm{D}_{\mathrm{i}-1}\right) /\left(\mathrm{T}_{\mathrm{i}}-\mathrm{T}_{\mathrm{i}-1}\right)
$$

with $\mathrm{D}_{\mathrm{i}}$ and $\mathrm{T}_{\mathrm{i}}$ the depth and age of the sample, and $\mathrm{D}_{\mathrm{i}-1}$ and $\mathrm{T}_{\mathrm{i}-1}$ the depth and age of the stratigraphically younger sample.

Although this approach was applied to all radiocarbon data most of these results are hard to interpret since the majority of cores in the Büğdüz and A ğlasun river catchments contained only few datable samples, a very common problem (e.g. Hoffmann et al., 2008). For the 10 $\mathrm{km}^{2}$ Gravgaz basin (Fig. 1), however, 10 cores with detailed stratigraphical description and dated by 33 radiocarbon samples were available (Six et al., 2008; Fig. 4). This basin is drained through a small karstic outlet, hence the sediment export from it is assumed to be insignificant. Additionally, for the Bereket basin (Fig. 5) four well-dated $(n=22)$ cores were available (Kaniewski et al., 2007a and this study; Fig. 6). The relatively large amount of data within these small-scale catchments allowed for a detailed scrutiny of the local variability of valley sedimentation. In the Gravgaz basin it was even possible to estimate the total sediment volume stored in the closed basin (Fig. 7), enabling us to calculate average hillslope erosion rates $\left(\mathrm{E}_{\mathrm{avg}}\right)$ :

$$
E_{\text {avg }}=\frac{S_{m}}{A_{\text {tot }}-A_{\text {dep }}} \times \frac{1}{B D_{\text {avg }}}
$$

Where $S_{m}$ is the total mass of sediment stored within the depositional zone in the Gravgaz valley; $\mathrm{A}_{\text {tot }}$ is the total catchment area; $\mathrm{A}_{\mathrm{dep}}$ is the depositional zone area; $\mathrm{BD}_{\mathrm{avg}}$ is the average bulk density of the hillslope topsoil $\left(1.35 \mathrm{t} / \mathrm{m}^{3}\right.$, analogous to Hoffmann et al., 2008). In order 
to assess the uncertainty on the calculated valley bottom storage, a Monte Carlo approach was used. This approach was taken because the age datum provided by radiocarbon dating is uncertain within a certain time interval. Therefore, 2000 Monte Carlo iterations were calculated, in which the age datum for each radiocarbon dated sample was randomly chosen within its confidence interval, proportional with its calibrated age likelihood. These ages were then used to calculate sedimentation rates using equation (1). The result of this uncertainty analysis is shown in Fig. 7.

Sedimentation rates vary significantly depending on the core's geomorphic setting and the age of the deepest stratigraphical layer reached. Additionally, radiocarbon dating density and hence temporal resolution strongly differs between cores, blurring the comparison between the $\mathrm{SR}_{\mathrm{a}}$ of individual cores and between distinct study areas. To overcome these problems, Hoffmann et al. (2009) and Notebaert et al. (2011a) suggest the use of mean sedimentation rates $\left(\mathrm{SR}_{\mathrm{m}}\right)$, calculated as follows:

$$
\mathrm{SR}_{, \mathrm{m}, \mathrm{i}}=\left(\mathrm{D}_{\mathrm{i}}\right) /\left(\mathrm{T}_{\mathrm{i}}\right)
$$

315 with $D_{i}$ and $T_{i}$ as defined above. The principal advantage of this approach is that it allows for the comparison between cores with different sampling densities. However, this approach assumes that aggradation was continuous since the sample age datum, which might be problematic if an erosion hiatus is present (Sadler effect: Sadler, 1981). The interpretation of $\mathrm{SR}_{\mathrm{m}}$ graphs may be less straightforward than the interpretation of $\mathrm{SR}_{\mathrm{a}}$ diagrams, but the use of $\mathrm{SR}_{\mathrm{m}}$ allows for the application of a simple modelling approach, which can provide additional insight into the chronological database (Hoffmann et al., 2009; Notebaert et al., 2011a).

The modelling approach takes advantage of the straightforward $\mathrm{SR}_{\mathrm{m}}$ calculation. Model input consists of $\mathrm{SR}_{\mathrm{a}}$ per period of 100 years over the last 10000 years, from which the $\mathrm{SR}_{\mathrm{m}}$ at each point in time is calculated. A Monte Carlo modelling approach was applied to explore the sedimentation rate trend in alluvial overbank deposits over the last 4000 years. Following the visual inspection of the $\mathrm{SR}_{\mathrm{m}}$ graph, a period of enhanced sedimentation rates during the first millennium BC was modelled, as well as an increase to modern rates during the last several centuries. The start of the first millennium BC enhanced sedimentation was varied from 1000 $\mathrm{BC}$ to $0 \mathrm{AD}$, and its duration was varied from 100 to 1000 years. The onset of the recent increase was varied between $1300 \mathrm{AD}$ and $1900 \mathrm{AD}$. Moreover, sedimentation rates during the peak periods were varied from 2 to $15 \mathrm{~mm} \mathrm{a}^{-1}$. Overall, the over 160000 model runs were evaluated using the Model Efficiency (ME; Nash and Sutcliffe, 1970): 


$$
M E=1-\frac{\sum_{i=1}^{n}(\mathrm{Oi}-\mathrm{Pi})^{2}}{\sum_{i=1}^{n}(\mathrm{Oi}-\text { Omean })^{2}}
$$

335 With $\mathrm{O}_{\mathrm{i}}$ the individual radiocarbon dated $\mathrm{SR}_{\mathrm{m}}$ (observations), $\mathrm{P}_{\mathrm{i}}$ the model-predicted $\mathrm{SR}_{\mathrm{m}}$ for each individual observation and $\mathrm{O}_{\text {mean }}$ the average of all observed $\mathrm{SR}_{\mathrm{m}}$.

It must be noted that the high alluvial $\mathrm{SR}_{\mathrm{m}}$ during recent centuries on the right hand side of Fig. 8 were omitted from the modelling approach. These samples are located directly behind a dam, and represent direct anthropogenic alterations to the geomorphic system rather than the impact of changing land use and climate on the hillslope-floodplain geomorphic processes.

\section{Results}

\section{Cumulative probability distribution analysis}

These CPD plots are based on relatively limited data; therefore only general trends are described. The cumulative probability distributions (Fig. 9) provide information on the principal periods of geomorphic activity as preserved within sediment archives from different geomorphologic situations. The CPD of colluvial ages (Fig. 9A; n=57) shows major activity phases around $900-400 \mathrm{BC}$ and the $7^{\text {th }}$ century AD and minor activity around $4000 \mathrm{BC}$ and generally since 2000 BC. Upper river valley ages (Fig. 9B; n=23), on the other hand, show major activity generally since $2000 \mathrm{BC}$ and a marked gap from 0-300 AD. Minor activity is observed around $6600 \mathrm{BC}$ and $3600 \mathrm{BC}$. The CPD of lower river valley ages (Fig. 9C; n=30) shows major activity around $1000 \mathrm{BC}$ and from 1400 AD until present.

\section{Temporal analysis of sediment accumulation at Gravgaz and Bereket}

355 A detailed sedimentation chronology was established for the $10 \mathrm{~km}^{2}$ Gravgaz catchment (Fig. 7). Generally, valley sedimentation was limited prior to $850 \mathrm{BC}$ (below $300 \mathrm{t} \mathrm{a}^{-1}$; Fig. 7), corresponding to an average hillslope erosion rate $\left(E_{a v g}\right)$ of $0.03 \mathrm{~mm} \mathrm{a}^{-1}$. From $850 \mathrm{BC}$ onwards, valley sedimentation increased dramatically, peaking between $525 \mathrm{BC}$ and $300 \mathrm{BC}$ $\left( \pm 2700 \mathrm{t} \mathrm{a}^{-1} ; \mathrm{E}_{\mathrm{avg}}=0.28 \mathrm{~mm} \mathrm{a}^{-1}\right)$. After this peak valley sedimentation stabilized at 1300 $1500 \mathrm{t} \mathrm{a}^{-1}\left(\mathrm{E}_{\mathrm{avg}}=0.14-0.16 \mathrm{~mm} \mathrm{a}^{-1}\right)$. Two minor peaks $\left( \pm 1900 \mathrm{t} \mathrm{a}^{-1} ; \mathrm{E}_{\mathrm{avg}}=0.20 \mathrm{~mm} \mathrm{a}^{-1}\right)$ are observed between 0-300 AD and 940-1130 AD (Fig. 7). The amplitude of the latter peak is highly uncertain, as it relies on closely related radiocarbon data within one single core. Similar to Gravgaz, the Bereket basin represents a closed depression, since the valley outlet was at least partially blocked by a fan originating from a colluvial zero-order valley until the $20^{\text {th }}$ century (Kaniewski et al., 2007a; Fig. 8). Sedimentation rates for this valley were 
obtained from four cores (Fig. 6), and spatial variability is similarly significant as in the Gravgaz valley. This variability appears to be due to the differing geomorphic situation between the cores (Fig. 5), as core SA10GV-B13 is located in a zero-order colluvial valley, while core SA09JB-Drill02 is situated on a small colluvial fan at the outlet of a steeper zeroorder catchment; cores BKT1 and BKT 2 (Kaniewski et al., 2007a) are situated in the centre of the former Bereket marsh (Fig. 4). Moreover, the averaging effect for relatively poorly dated time periods is significant, as illustrated for both the Bereket and Gravgaz basins (Fig. $10)$.

\section{Mean sedimentation rate analysis}

Regional-scale mean colluvial and alluvial sedimentation rates $\left(\mathrm{SR}_{\mathrm{m}}\right)$ show strongly differing trends (Fig. 8). Colluvial sedimentation was rather constant in the last 4000 years, indicating relatively continuous sediment fluxes at small spatial scales. Alluvial sedimentation rates, conversely, peak during the first millennium BC and during recent centuries. This signal

380 results from fluvial processes directly linked to hillslope erosion, such as overbank deposition, but floodplain reworking and channel migration may also be significant.

The results of the Monte Carlo modelling approach (Fig. 11 and 12) show that scenarios with an early increase in sedimentation rate of short duration during the first millennium BC fits best to the field data. Moreover, the increase in sedimentation rates towards the modern values also started rather early, during the late Middle Ages. However, the Monte Carlo simulations did not predict the amplitude of the enhanced sedimentation well (Fig. 12).

\section{Discussion}

To establish a chronology of geomorphic system response to past environmental change, most palaeo-environmental research in the Eastern Mediterranean relies on data which are spatially severely limited (e.g. Eastwood et al., 1999; Kaniewski et al., 2007a). Therefore, in order to establish a detailed chronology of geomorphic response to Holocene environmental change for the territory of Sagalassos, a large database comprising 178 data was assembled. Although this is the largest database on sediment dynamics in the late Holocene for the entire Eastern

395 Mediterranean Region, the available data is still severely limited. For instance, in the $260 \mathrm{~km}^{2}$ Büğdüz river system 31 valley cross-sections were investigated and 14 yielded reliable radiocarbon data, but only from six cross-sections three or more radiocarbon samples could be retrieved. The limited availability of datable organic remains in floodplain deposits of Eastern Mediterranean rivers results in such imperfect temporal information: some time periods are 
represented rather poorly in the database compared to other periods. This is problematic as the length of the time period over which sedimentation rates are integrated strongly influences the resulting sedimentation rates (Fig. 10). The Sagalassos radiocarbon database was analyzed combining multiple approaches in order to establish a temporal framework of geomorphic activity and sediment fluxes during the Holocene. Consequently, general trends could be detected for specific depositional environments, such as alluvial and colluvial deposits. The integration of data from multiple case studies into one database is not unproblematic, since each radiocarbon dated sample was taken bearing a specific research objective in mind. For example, the study by Kaniewski et al. (2007a) at Bereket focused primarily on the ClassicalHellenistic and Roman time periods (roughly from 500 BC to 700 AD) and the research objective of core SA09JB-Drill02 is to study specifically the post-Roman environmental changes. Although the differing level of temporal detail for various periods hampers proper interpretation, it is evident that sedimentation rates between single coring locations differ strongly for sub-periods of the late Holocene.

415 In the Bereket valley, a significant time lag can be observed between sedimentation in the upper, zero-order colluvial valleys (core SA10GV-B13) and the lower main valley (cores BKT1 and BKT 2: Kaniewski et al., 2007a; core SA09JB-Drill02). This time lag may be due to all core locations being situated in different geomorphic settings (Fig. 5): core SA10GVB10 is located in a small upland colluvial valley; cores BKT1 and BKT 2 (Kaniewski et al., 420 2007a) are located in the marsh upstream the valley-blocking colluvial fan; core SA09JBDrill02 is located right on a smaller colluvial fan at the outlet of a small zero-order valley coming from the south. This example indicates the importance of a proper geomorphic mapping of a basin for a reliable reconstruction of its sedimentation history. Point based information may not be representative of the evolution of the larger geomorphic system. The reconstruction of the latter requires an approach integrating data from multiple geomorphic situations. These results clearly show that a reconstruction of the sediment dynamics, as well as its interpretation in terms of climate or land use change, based on a single or even a limited number of corings has no scientific basis (Richards, 2002). Poorly dated cores result in less detailed $\mathrm{SR}_{\mathrm{a}}$ curves and yield lower peak sedimentation rates. Combining all available data 430 for the Gravgaz basin allowed establishing a sediment accumulation chronology in the valley bottom. To quantify sediment storage, however, detailed information concerning core stratigraphy, organic matter content and sediment bulk density is necessary. All these factors influence the total mass of accumulated sediment (Fig. 7). Peat growth in the central marsh 
area of the Gravgaz valley increased from about 650 BC onward, due to decreased hillslopederived sediment input. When sediment bulk density and thus organic matter content are taken into account, the results provide a more reliable sedimentation history than a pure volumetric approach does, which in itself is already better than the analysis of site-specific sedimentation rates.

440 Also at other locations in the territory of Sagalassos multiple dated cores were available. In the Ağlasun River and Çanaklı valleys (Six, 2004), however, a detailed sedimentation history analysis for the last few millennia was not possible. Firstly, radiocarbon data from both catchments are significantly older than in the western part of the territory of Sagalassos, resulting in a low temporal resolution of the sediment archives during recent periods.

445 Secondly, sediment archive stratigraphies are hard to interpret due to the presence of step-like travertine dams in the Ağlasun River floodplain (Degryse et al., 2008). In the $110 \mathrm{~km}^{2}$ Çanaklı basin only two cores were available. These cores are situated near the north-western edge of the basin, making their catchment-wide significance doubtful.

450 The analysis of mean sedimentation rates $\left(\mathrm{SR}_{\mathrm{m}}\right)$ provides information about the timing and intensity of past geomorphic activity. This approach, however, is sensitive to averaging effects, since the longer the integration time period, the higher the likelihood over variations in sedimentation rates or the occurrence of erosion (Sadler, 1981; Fig. 10). The so-called Sadler effect may hamper the interpretation of $\mathrm{SR}_{\mathrm{m}}$, especially in systems with discontinuous 455 sedimentation and the possible occurrence of erosion phases, like the Sagalassos territory. However, from sedimentological analysis it was concluded that erosion phases erosion phases during the Holocene were insignificant in colluvial valleys such as at Gravgaz (Six et al., 2008) and Bereket (Kaniewski et al., 2007a). The same applies most likely to the upper river valleys in the territory of Sagalassos, since these represent similar geomorphic situations.

460 However, in the lower Büğgüz river valley, at least one significant erosion hiatus, dated to around $0 \mathrm{AD}$, was found in one floodplain cross-section. This hiatus influences the obtained $\mathrm{SR}_{\mathrm{m}}$ for samples older than the erosion phase, and the $\mathrm{SR}_{\mathrm{a}}$ calculations for periods which include the erosion phase. Nevertheless, it is evident that this hiatus does not obliterate the significant peak in observed $\mathrm{SR}_{\mathrm{m}}$ during the first millennium BC (Fig. 11). Additionally, the number of samples affected by this erosion hiatus adds up to only $15 \%$ of the alluvial data used in the analysis. It must be noted that interpretation of the $\mathrm{SR}_{\mathrm{m}}$ analysis is only valid over a centennial time scale (Fig. 12). 
The combination of the $\mathrm{SR}_{\mathrm{m}}$ analysis and the Monte Carlo model simulations provides further insight into the Holocene sediment dynamics. Enhanced sedimentation started early in the first millennium BC (most probably around 700 to $800 \mathrm{BC}$, and the peak period was of relatively short duration (200-300 years). Moreover, the rise towards contemporary sedimentation rates started already during the $14^{\text {th }}$ century. The amplitude of the sedimentation rate peaks, however, is less obvious from the modelling results. The best 475 sedimentation rate scenarios for the Sagalassos region differ strongly from the pattern of sedimentation rates modelled for western European regions (e.g. Hoffmann et al., 2009; Notebaert et al., 2011a). Geomorphic activity in the Eastern Mediterranean seems to have started well before the large settlement expansion of the Hellenistic and Roman periods indicated by archaeological evidence. However, the peaks in sedimentation do correspond to an increase in archaeologically visible activity in the region. In the territory of Sagalassos, the peak that started around 800 or $700 \mathrm{BC}$ corresponds to the start of the Archaic period when, after a period devoid of artefacts, several settlements appear. These settlements are still limited in number but often located at hilltops. Forest clearing on slopes, e.g. for building material, fuel, or to attain agricultural fields, will have impacted sedimentation much more than similar activities in the valley bottoms. To a smaller degree this also applies to the peak in the $14^{\text {th }}$ century BC, when Late Bronze Age (1450 - 1180 BC) hilltop sites were first founded after the as of yet elusive Middle Bronze Age (2000 - 1450 BC) (Vanhaverbeke and Waelkens, 2003). Later, sediment dynamics declined, probably due to interplay between changing strategies for settlement location and land use, the declining pressure on the 490 landscape after the Roman period, and the depletion of the soil reservoirs in the region. Similar soil depletion-driven land use changes were also observed in Lesvos, Greece during the $20^{\text {th }}$ century (Bakker et al., 2005). The recent increase in sedimentation rates, on the other hand, may be related to more intensive agricultural activity on the lower hillslopes and floodplains. Additionally, recent landscape modification by engineering works such as terrace construction, dam building and the construction of irrigation systems also has an indirect impact on sediment dynamics. In Western Europe, and more specifically in the loess belt, geomorphic activity increased rather continuously during the late Holocene, in line with the continuous increase in anthropogenic pressure on the landscape through land use changes, mainly deforestation (Hoffmann et al., 2008; Notebaert et al., 2011a; Notebaert et al., 2011b).

500 Moreover, soil depletion in the loess belt is not an issue, since soils are homogeneous and deep. 
To discuss the role of the driving factors in the timing of geomorphic activity, first the changes in these driving factors must be assessed. Climate and vegetation changes in the Eastern Mediterranean during the Holocene are discussed in detail by Dusar et al. (2011). Apart from the natural variations, mainly expressed by periods of relative wetness or dryness similar to the Medieval warm period or Little Ice Age in Western Europe (Bakker et al., accepted), human impact on the geomorphic system was obviously important during the late Holocene in the Eastern Mediterranean. In the Sagalassos territory, palaeo-environmental investigations have resulted in very well established chronologies of natural and humaninduced environmental change (Vermoere et al., 1999; 2000; 2001; 2002; Kaniewski et al., $2007 \mathrm{a} ; 2007 \mathrm{~b} ; 2008)$. Comparing the land use and climate history with the chronological analysis of geomorphic activity in the territory of Sagalassos, it is observed that the initial landscape-wide disturbance by man, mainly through deforestation, during the early first millennium BC (Fig. 2) coincided with a major sedimentation pulse in the small-scale basins of Gravgaz and Bereket. A similar response to the initial human disturbance is reported by various studies in the Eastern Mediterranean (e.g. Bintliff, 2002; Fuchs, 2007; Lespez, 2003), but these studies do not indicate the declining intensity of geomorphic activity during subsequent periods of even more enhanced landscape pressure. For Gravgaz and Bereket detailed palynological data are available, which allows for the proposition of another hypothesis of the principal driving forces of hillslope soil erosion. The relation with the regional settlement history is not obvious, however, probably due to the relative lack of data concerning the period before $350 \mathrm{BC}$.

The timing of alluvial sedimentation obtained from the CPD and $\mathrm{SR}_{\mathrm{m}}$ analysis shows a time lag between upper and lower valley floodplains in the territory of Sagalassos. In small scale colluvial valleys such as the Gravgaz basin, enhanced sedimentation coincided with the initial landscape disturbance, and time lags between individual cores were not significant. In Bereket, the temporal variation in sedimentation rates between the three coring locations may at least partly due to their differing geomorphic situation, as well as variable landscape disturbance in the sub-catchments, as opposed to actual time lags within the same geomorphic system. The upper Büğdüz River valley floodplains largely show a similar sedimentation history during the late Holocene. The onset of floodplain overbank sedimentation in the lower reaches, however, shows a time lag of several centuries (Fig. 9) compared to the upper and colluvial valleys. This time lag is partly explained by the changing land use pattern from the 
Hellenistic towards the Roman period and the increased agricultural activity on the easily accessible hillslopes directly bordering the Büğgüz River trunk valley. Both factors enhanced connectivity of the geomorphic system, on the one hand between upper and lower valley floodplains, on the other hand from the lower hillslopes towards the trunk valley.

540

Results from this study show that spatial variability in past sedimentation rates cannot be neglected in the Eastern Mediterranean. Therefore, chronologies of late Holocene geomorphic activity obtained in this region must be critically reviewed, since most studies rely on limited coring data, or investigate a single type of sediment archive (Dusar et al., 2011). In Western

545 Europe, Australia and the USA sediment budgets integrating the different components of the entire sediment pathway throughout the geomorphic system have been established indicating the temporal variability between sub-periods of the late Holocene (e.g. Fryirs and Brierley, 2001; Trimble, 1999; Notebaert et al., 2009). This implies that research cannot concentrate on one location or one type of sediment archive to establish a chronology of past geomorphic activity, since the signal recorded in e.g. colluvial or lacustrine sediment archives is strongly dependent on the configuration of the geomorphic system at that time. Therefore, past geomorphic system can only be studied by integrating data from multiple locations and various types of sediment archives. Moreover, the application of quantifying approaches and geomorphic modelling is recognized (Dusar et al., 2011), and will be applied on the study area. Still, this study provides an indication of the potential of this integrative approach in the Eastern Mediterranean region. Results from small endorheic colluvial basins can be combined and compared to the chronology of geomorphic activity in a much larger river basin. However, this study does not rely on single archives to come to regional scale conclusions, but rather combines a large array of data from previous and present-day research. This is probably the largest distinction between this study and much geo-chronological research in the Eastern Mediterranean, as discussed by Dusar et al. (2011).

\section{Conclusions}

In this study, a database of 178 AMS radiocarbon ages was assembled from the $1000 \mathrm{~km}^{2}$

565 Sagalassos territory in south-western Turkey. This database was analyzed using cumulative probability distributions, sedimentation rates and a Monte Carlo modelling approach (Fig. $13)$. 
Results indicate that variability between individual cores is significant due to differences in local geomorphic situation. Therefore, single sediment archives cannot be used for landscape reconstruction purposes, since the temporal variation in connectivity between landscape elements is significant. Additionally, the settlement history and land use history in the territory of Sagalassos show that historical human landscape disturbance is diachronic. This partly explains time lags between various parts of the geomorphic system. As a result, variations in sediment fluxes and sedimentary archives in different parts of the geomorphic landscape do not show a linear relationship with driving force variations. Harvey (2001, 2002) demonstrates how variations in connectivity between different parts of the sediment pathway influence the relative importance of the different sedimentary sinks. While colluvial deposits in zero-order valleys are more likely to be directly influenced by changes in erosion rates due to their spatial connection, downstream floodplains may show a less direct link due to buffering by intermediate sinks. Therefore, the link between driving forces and geomorphic response is much harder to establish for larger river systems (Trimble, 1999). This paper provides evidence that this issue also applies to the Eastern Mediterranean: sedimentation rate studies from lakes, colluvial deposits, river mouths and generally single locations within the geomorphic landscape do not record overall changes in geomorphic activity within their catchment area. Therefore, multiple locations within the landscape must be dated and investigated in order to establish a chronology at various scales and for different processes (Verstraeten et al., 2009). The application of cumulative probability distribution analysis on a regional database containing chronological information about geomorphic activity can 590 indicate the principal periods of geomorphic activity. Sedimentation rate analysis aided by a modelling approach allows for the assessment of the timing and duration of the most important activity phases.

Results from the CPD and $\mathrm{SR}_{\mathrm{m}}$ analysis show the contrast in timing and sedimentation rates of colluvial deposits versus alluvial deposits. Colluviation occurred continuously over the last four millennia, although a distinct major activity phase was observed around 500 BC. Since then, colluvial sedimentation rates apparently have remained constant. On the other hand, upper valley alluviation peaked in the first half of the $1^{\text {st }}$ millennium $\mathrm{BC}$, with significantly less activity afterwards. The same applies to lower valley alluviation, although sediment 600 deposition was more important during the $2^{\text {nd }}$ millennium AD. The results from the CPD and MSR analysis mutually agree, however (Fig. 13). 
Chronologies established for the small-scale colluvial basins of Gravgaz and Bereket have shown that a first disturbance phase caused a marked hillslope erosion peak and hence enhanced valley sedimentation rates. Still, they do not agree on the timing of the initial, widespread landscape disturbance. After the initial phase valley sedimentation rates decreased, to only rise again during the last several centuries. Comparing with palynological information, the timing of this initial pulse appears to coincide with important human-induced land-use changes. Its amplitude, along with subsequent declining sedimentation rates, was

610 determined by the landscape sensitivity towards erosion. Hillslope soils in the Eastern Mediterranean are relatively shallow, and they get progressively deprived of erodible material with ongoing erosion, causing sedimentation rates to decline. At a larger scale, alluvial sedimentation shows principally the same trend, although slightly delayed. This time lag appears to increase further down the Büğdüz river system, since the systems' buffering

615 capacity probably slowed the propagation of the upstream signal for a certain time period.

In order to further test the possible causes for the observations drawn from this studies' database analysis, further dating refinement is needed, as well as the application of a geomorphic landscape evolution model (cfr. Notebaert et al., 2011b; Peeters et al., 2006).

620 This model should take land use and climate change into account, along with the specific landscape characteristics of the Eastern Mediterranean, such as soil depth and topsoil stone content, both significantly affecting soil erosion in the region. Combined with reliable chronological research, it can form the basis of a holistic investigation approach towards the history of Mediterranean landscapes.

\section{Acknowledgements}

This research is part of a project funded by the Concerted Action of the Flemish Government (GOA project nr. 3H051017), along with support from the Belgian Program on Interuniversity Poles of Attraction (IUAP 6/22) initiated by the Belgian State, Prime Minister's Office,

630 Science Policy Programming. The support of the Centre for Archaeological Science at the K.U.Leuven is also gratefully acknowledged. Moreover, the authors would like to thank Jeroen Poblome and other staff members of the Sagalassos Archeological Research Project for their administrative and logistic support during the field campaigns. The support of Evelien Janssens, Jozefien Hermy, Martijn Claes, Koen Vereycken, Jill Haex, Koen De

635 Munter, Iris Deliever, Benjamin Campforts, Elena Marinova, Véronique De Laet and Bastiaan Notebaert during field work is greatly appreciated 
. A large part of the radiocarbon database (Gravgaz, Ağlasun Çayı and part of Bereket) was gathered by Etienne Paulissen, Simon Six, David Kaniewski and Marleen Vermoere.

\section{$640 \quad$ References}

Bakker MM, Govers G, Kosmas C, Vanacker V, van Oost K, Rounsevell M. 2005. Soil erosion as a driver of land-use change. Agriculture, Ecosystems and Environment 105: 467481.

645 Beach TP, Luzzadder-Beach S. 2008. Geoarchaeology and aggradation around Kinet Höyük, an archaeological mound in the Eastern Mediterranean, Turkey. Geomorphology 101: 416428.

Bintliff J. 2002. Time, process and catastrophism in the study of Mediterranean alluvial history: A review. World Archaeology 33: 417-435.

Bronk Ramsey C. 2001. Development of the radiocarbon calibration program Oxcal. Radiocarbon 43 (2A): 355-363.

655 Bronk Ramsey C. 2009. Bayesian analysis of radiocarbon dates. Radiocarbon 51 (1): 337 360.

Brückner H, Müllenhoff M, Gehrels R, Herda A, Knipping M, Vött A. 2006. From archipelago to floodplain - geographical and ecological changes in Miletus and its environs during the last six millennia (Western Anatolia, Turkey). Zeitschrift für Geomorphologie Suppl. vol. 142: 63-83.

Casana J. 2008. Mediterranean valleys revisited: Linking soil erosion, land use and climate variability in the Northern Levant. Geomorphology 101: 429-442.

Chiverrell RC, Thorndycraft VR, Hoffmann TO. 2011a. Cumulative probability functions and their role in evaluating the chronology of geomorphological events during the Holocene. Journal of Quaternary Science 26: 76-85. 
670 Chiverrell RC, Thorndycraft VR, Hoffmann TO. 2011b. Reply to comment: Cumulative probability functions and their role in evaluating the chronology of geomorphological events during the Holocene. Journal of Quaternary Science 26 (2): 241-244.

Degryse P, Muchez P, Viaene W, Quinif Y, Waelkens M. 2008. Depositional environment of 675 Holocene cool water travertines in the valley of Başköy (southwestern Turkey). In Sagalassos VI. Geo- and Bio-Archaeology at Sagalassos and in its Territory, Degryse P, Waelkens M editors. Leuven University Press: Leuven; 211-214.

De Laet V. 2007. Evolution and reconstruction of the geo-archaeological landscape in the territory of Sagalassos (SW Turkey): Integration of geomorphic, GIS and remote sensing methods. PhD thesis. KU Leuven, Belgium

Dusar B, Verstraeten G, Notebaert B, Bakker J, 2011. Holocene environmental change and its impact on sediment dynamics in the Eastern Mediterranean. Earth Science Reviews 108: 137685 157. Doi: 10.1016/j.earscirev.2011.06.006

Eastwood WJ, Roberts N, Lamb HF, Tibby JC. 1999. Holocene environmental change in southwest Turkey: a palaeoecological record of lake and catchment-related changes.

Quaternary Science Reviews 18: 671-695.

690

Fuchs M. 2007. An assessment of human versus climatic impacts on Holocene soil erosion in NE Peloponnese, Greece. Quaternary Research 67: 349-356.

Glover CP, Robertson AHF. 1998. Role of regional extension and uplift in the Plio695 Pleistocene evolution of the Aksu Basin, SW Turkey. Journal of the Geological Society, London 155: 365-387.

Harden T, Macklin MG, Baker VR. 2010. Holocene flood histories in south-western USA. Earth Surface Processes and Landforms 35: 707-716.

Harvey AM. 2001. Coupling between hillslopes and channels in upland fluvial systems: implications for landscape sensitivity, illustrated from the Howgill Fells, northwest England. Catena 42: 225-250. 
Harvey AM. 2002. Effective timescales of coupling within fluvial systems. Geomorphology 44: 175-201.

Hoffmann T, Lang A, Dikau R. 2008. Holocene river activity: analysing C-14-dated fluvial and colluvial sediments from Germany. Quaternary Science Reviews 27: 2031-2040.

Hoffmann T, Erkens G, Gerlach R, Klostermann J, Lang A. 2009. Trends and controls of Holocene floodplain sedimentation in the Rhine catchment. Catena 77: 96-106.

Kale VS. 2007. Fluvio-sedimentary response of the monsoon-fed Indian rivers to Late

Pleistocene-Holocene changes in monsoon strength: reconstruction based on existing C-14 changes. Quaternary Science Reviews 26: 1610-1620.

Kaniewski D, Paulissen E, De Laet V, Dossche K, Waelkens M. 2007a. A high-resolution Late Holocene landscape ecological history inferred from an intramontane basin in the Western Taurus Mountains, Turkey. Quaternary Science Reviews 26: 2201-2218.

Kaniewski D, De Laet V, Paulissen E, Waelkens M. 2007b. Long-term effects of human impact on mountainous ecosystems, western Taurus Mountains, Turkey. Journal of Biogeography 34: 1975-1997.

Kaniewski D, Paulissen E, De Laet V, Waelkens M. 2008. Late Holocene fire impact and post-fire regeneration from the Bereket basin, Taurus Mountains, southwest Turkey. Quaternary Research 70: 228-239.

730 Lang A. 2003. Phases of soil erosion-derived colluviation in the loess hills of South Germany. Catena 51: 209-221.

Lang A, Hönscheidt S. 1999. Age and source of colluvial sediments at Vaihingen-Enz, Germany. Catena 38: 89-107.

Lang A, Nolte S. 1999. The chronology of Holocene alluvial sediments from the Wetterau, Germany, provided by optical and C-14 dating. The Holocene 9: 207-214. 
Lang A, Bork HR, Mackel R, Preston N, Wunderlich E, Dikau R. 2003. Changes in sediment 740 flux and storage within a fluvial system: some examples from the Rhine catchment. Hydrological Processes 17: 3321-3334.

Lespez L. 2003. Geomorphic responses to long-term land use changes in Eastern Macedonia (Greece). Catena 51: 181-208.

Lewin J, Macklin MG, Johnstone E. 2005. Interpreting alluvial archives: sedimentological factors in the British Holocene fluvial record. Quaternary Science Reviews 24: 1873-1889.

Macklin MG, Lewin J. 2003. River sediments, great floods and centennial-scale Holocene climate change. Journal of Quaternary Science 18: 101-105.

Macklin MG, Benito G, Gregory KJ, Johnstone E., Lewin J, Michczynska DJ, Soja R, Starkel L, Thorndycraft VR. 2006. Past hydrological events reflected in the Holocene fluvial record of Europe. Catena 66: 145-154.

Macklin MG, Jones AF, Lewin J. 2010. River response to rapid Holocene environmental change: evidence and explanation in British catchments. Quaternary Science Reviews 29: 1555-1576.

760 Macklin MG, Jones AF, Lewin J. 2011. Comment: Cumulative probability functions and their role in evaluating the chronology of geomorphological events during the Holocene. Journal of Quaternary Science 26 (2): 238-240.

Montgomery, D. 2007. Dirt - The erosion of Civilizations. University of California Press, 294 765 pp.

Moore T, Rea D, Godsey H. 1998. Regional variation in modern radiocarbon ages and the hard-water effects in Lakes Michigan and Huron. Journal of Paleolimnology 20 (4): 347-351.

770 Nash JE, Sutcliffe JV. 1970. River flow forecasting through conceptual models, a discussion of principles. Journal of Hydrology 10: 282-290. 
Notebaert B, Verstraeten G, Rommens T, Vanmontfort B, Govers G, Poesen J. 2009.

Establishing a Holocene sediment budget for the river Dijle. Catena 77: 150-163.

775

Notebaert B, Verstraeten G, Vandenberghe D, Marinova E, Poesen J, Govers G. 2011a.

Changing hillslope and fluvial Holocene sediment dynamics in a Belgian loess catchment. Journal of Quaternary Science 26 (1): 44-58.

780 Notebaert B, Verstraeten G, Ward P, Renssen, H, Van Rompaey A. 2011b. Modeling the sensitivity of sediment and water runoff dynamics to Holocene climate and land use changes at the catchment scale. Geomorphology 126: 18-31.

Peeters I, Rommens T, Verstraeten G, Govers G, Van Rompaey A, Poesen J, Van Oost K. 785 2006. Reconstructing ancient topography through erosion modelling. Geomorphology 78: 250-264.

Reimer PJ, Baillie MGL, Bard E, Bayliss A, Beck JW, Blackwell PG, Bronk Ramsey C, Buck CE, Burr GS, Edwards RL, Friedrich M, Grootes PM, Guilderson TP, Hajdas I, Heaton TJ, 790 Hogg AG, Hughen KA, Kaiser KF, Kromer B, McCormac FG, Manning SW, Reimer RW, Richards DA, Southon JR, Talamo S, Turney CSM, van der Plicht J, Weyhenmeyer CE. 2009. IntCal09 and Marine09 radiocarbon age calibration curves, 0-50,000 years cal BP. Radiocarbon 51 (4): 1111-1150.

795 Richards, K. 2002. Drainage basin structure, sediment delivery and the response to environmental change. Geological Society Special Publication 191: 149-160.

Sadler P. 1981. Sediment accumulation rates and the completeness of stratigraphic sections. Journal of Geology 89: 569-584.

Six S. 2004. Holocene geomorphological evolution of the territory of Sagalassos. PhD thesis. Department Earth and Environmental Sciences, KU Leuven, Belgium.

Six S, Paulissen E, Van Thuyne T, Lambrechts J, Vermoere M, De Laet, V, Waelkens M, 2008. Late Holocene sediment characteristics and sediment accumulation in the marsh of 
Gravgaz: evidence for abrupt environmental changes. In Sagalassos VI. Geo- and BioArchaeology at Sagalassos and in its Territory, Degryse P, Waelkens M editors. Leuven University Press: Leuven; 189-210.

810 Starkel L, Soja R, Michczynska DJ. 2006. Past hydrological events reflected in the Holocene history of Polish rivers. Catena 66: 24-33.

Thorndycraft VR, Benito G. 2006a. Late Holocene fluvial chronology of Spain: The role of climatic variability and human impact. Catena 66: 34-41.

Thorndycraft VR, Benito G, 2006b. The Holocene fluvial chronology of Spain: evidence from a newly compiled radiocarbon database. Quaternary Science Reviews 25: 223-234.

Törnqvist T, Dejong A, Oosterbaan W, Vanderborg K. 1992. Accurate dating of organic deposits by AMS C-14 measurement of macrofossils. Radiocarbon 34 (3): 566-577.

Trimble SW. 1999. Decreased rates of alluvial sediment storage in the Coon Creek Basin, Wisconsin, 1975-93. Science 285: 1244-1246.

Turner JN, Macklin MG, Jones AF, Lewis, H. 2010. New perspectives on Holocene flooding in Ireland using meta-analysis of fluvial radiocarbon dates. Catena 82: 183-190.

Van Andel TH, Zangger E, Demitrack A. 1990. Land use and soil erosion in Prehistoric and Historical Greece. Journal of Field Archaeology 17 (4): 379-396.

Vanhaverbeke H, Waelkens M. 2003. The Chora of Sagalassos (Pisidia, southwest Turkey). The evolution of the settlement pattern from prehistory until recent times. Brepols Publishers: Turnhout, $362 \mathrm{pp}$.

835 Verhaert G, Similox-Tohon D, Vandycke S, Sintubin M, Muchez P. 2006. Different stress states in the Burdur-Isparta region (SW Turkey) since Late Miocene times: a reflection of a transient stress regime. Journal of Structural Geology 28: 1067-1083. 
Vermoere M, Degryse P, Vanhecke L, Muchez P, Paulissen E, Smets E, Waelkens M. 1999.

840 Pollen analysis of two travertine sections in Basköy (southwestern Turkey): implications for environmental conditions during the early Holocene. Review of Palaeobotany and Palynology 105: 93-110.

Vermoere M, Smets E, Waelkens M, Vanhaverbeke H, Librecht I, Paulissen E, Vanhecke L.

845 2000. Late Holocene environmental change and the record of human impact at Gravgaz near Sagalassos, Southwest Turkey. Journal of Archaeological Science 27: 571-595.

Vermoere M, Vanhecke L, Waelkens M, Smets, E. 2001. Modern pollen studies in the territory of Sagalassos (Southwest Turkey) and their use in the interpretation of a Late Holocene pollen diagram. Review of Palaeobotany and Palynology 114: 29-56.

Vermoere M, Bottema S, Vanhecke L, Waelkens M, Paulissen E, Smets E. 2002.

Palynological evidence for late-Holocene human occupation recorded in two wetlands in SW Turkey. The Holocene 12 (5): 569-584.

Vermoere M, Vanhecke L, Waelkens M, Smets E. 2003. Modern and ancient olive stands near Sagalassos (south-west Turkey) and reconstruction of the ancient Agricultural landscape in two valleys. Global Ecology \& Biogeography 12: 217-235.

860 Verstraeten G, Lang A, Houben P. 2009. Human impact on sediment dynamics quantification and timing. Catena 77: 77-80.

Waelkens M, Paulissen E, Vermoere M, Degryse P, Celis D, Schroyen K, De Cupere B, Librecht I, Nackaerts K, Vanhaverbeke H, Viaene W, Muchez P, Ottenburgs R, Deckers S, 865 Van Neer W, Smets E, Govers G, Verstraeten G, Steegen A, Cauwenberghs K. 1999. Man and environment in the territory of Sagalassos, a classical city in SW Turkey. Quaternary Science Reviews 18: 697-709.

Zielhofer C, Faust D. 2008. Mid- and late Holocene fluvial chronology of Tunisia. 


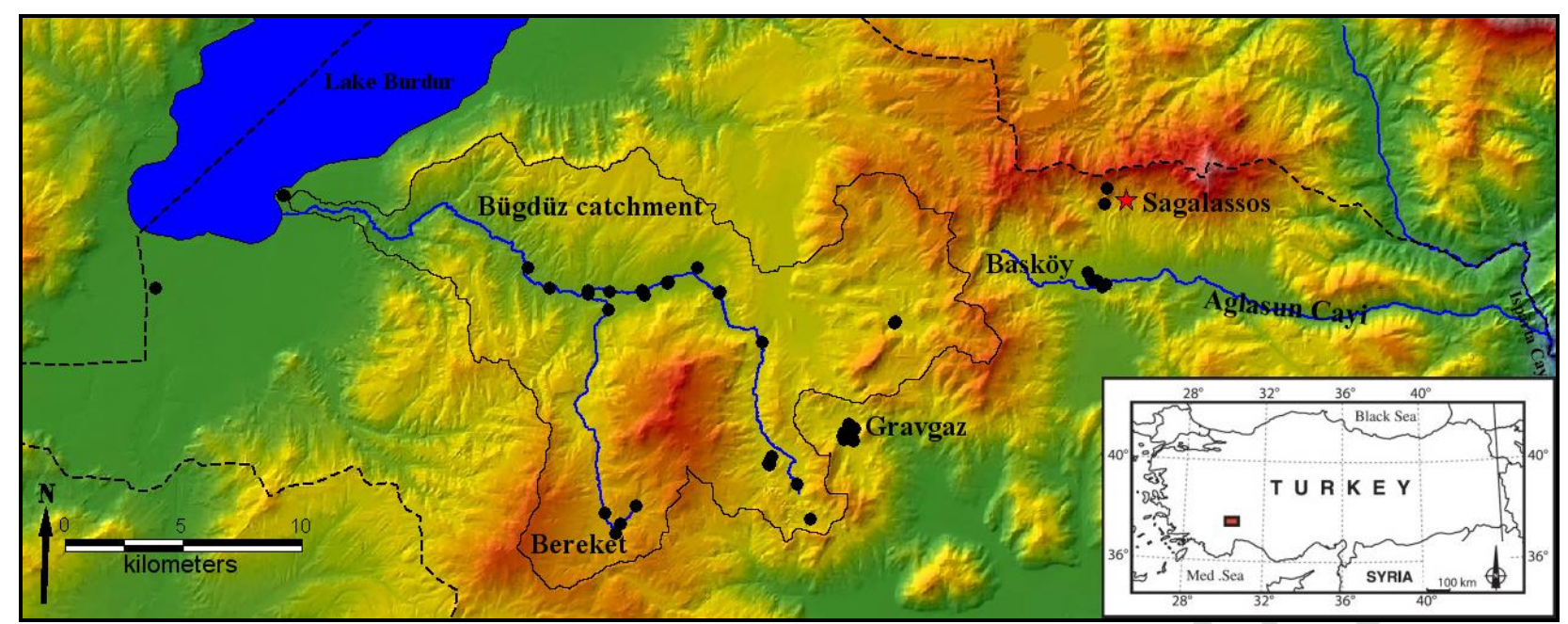

Fig. 1. Location of the territory of Sagalassos in south-western Turkey. All radiocarbon dated sediment archives are indicated (black dots), as well as the outline of the territory of Sagalassos

875 (dotted line) and the extent of the Büğdüz River catchment (continuous black line). The location of the ancient city of Sagalassos is also indicated (red star). 


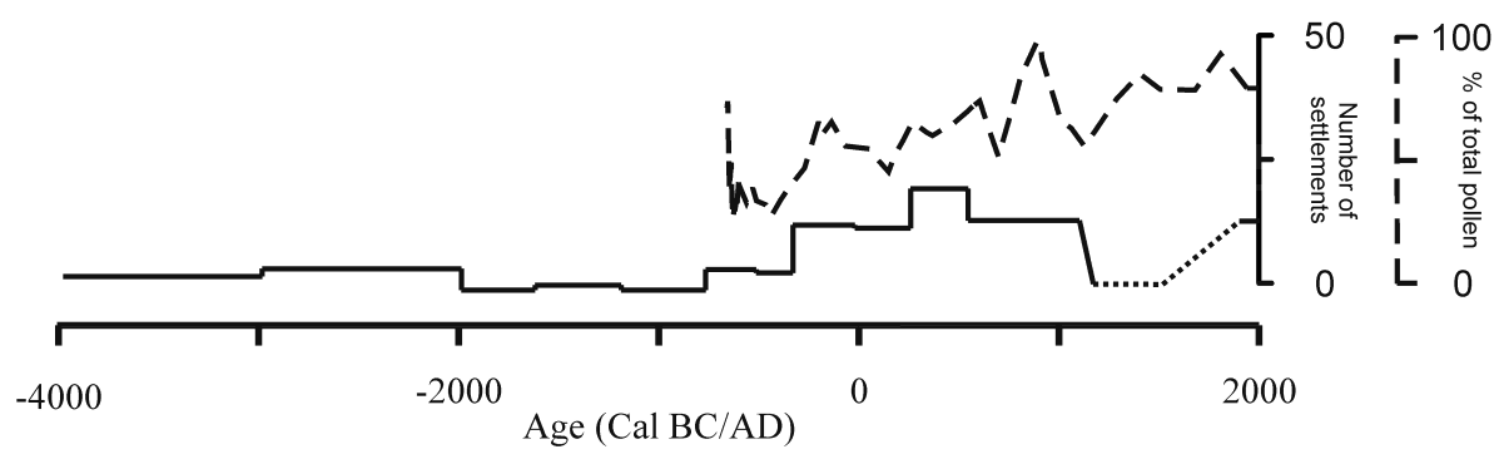

Fig. 2. Number of settlements in the territory of Sagalassos $\left( \pm 1000 \mathrm{~km}^{2}\right)$ per time period (full line; adapted from Vanhaverbeke and Waelkens, 2003) and arboreal pollen concentration at Gravgaz (broken line; Vermoere et al., 2002). 

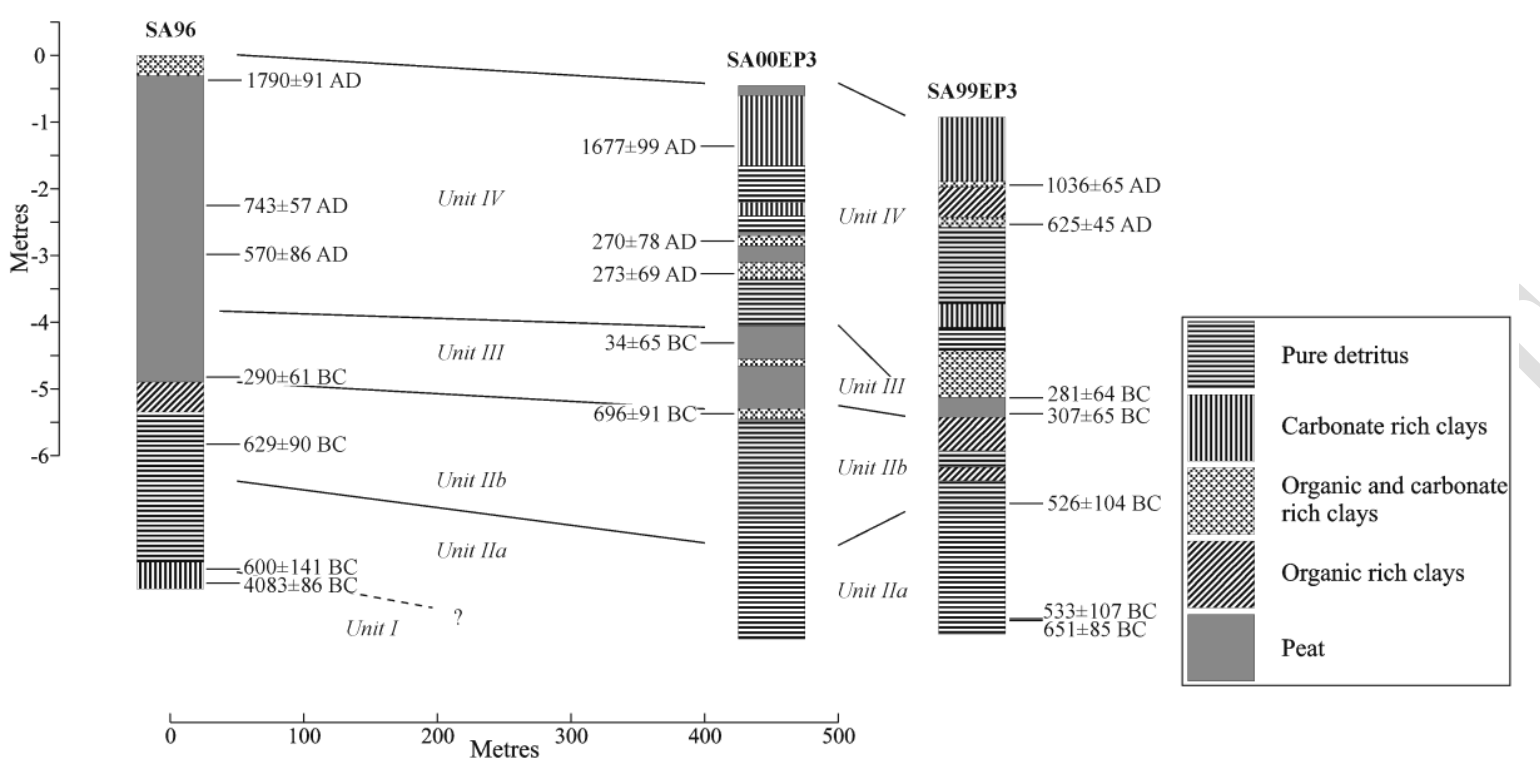

Fig. 3. Profile with three of the cores in the Gravgaz valley floor indicated. Sedimentology and radiocarbon dating was carried out by Six et al. (2008). This profile was redrawn based on Six (2004, pp. 136). 


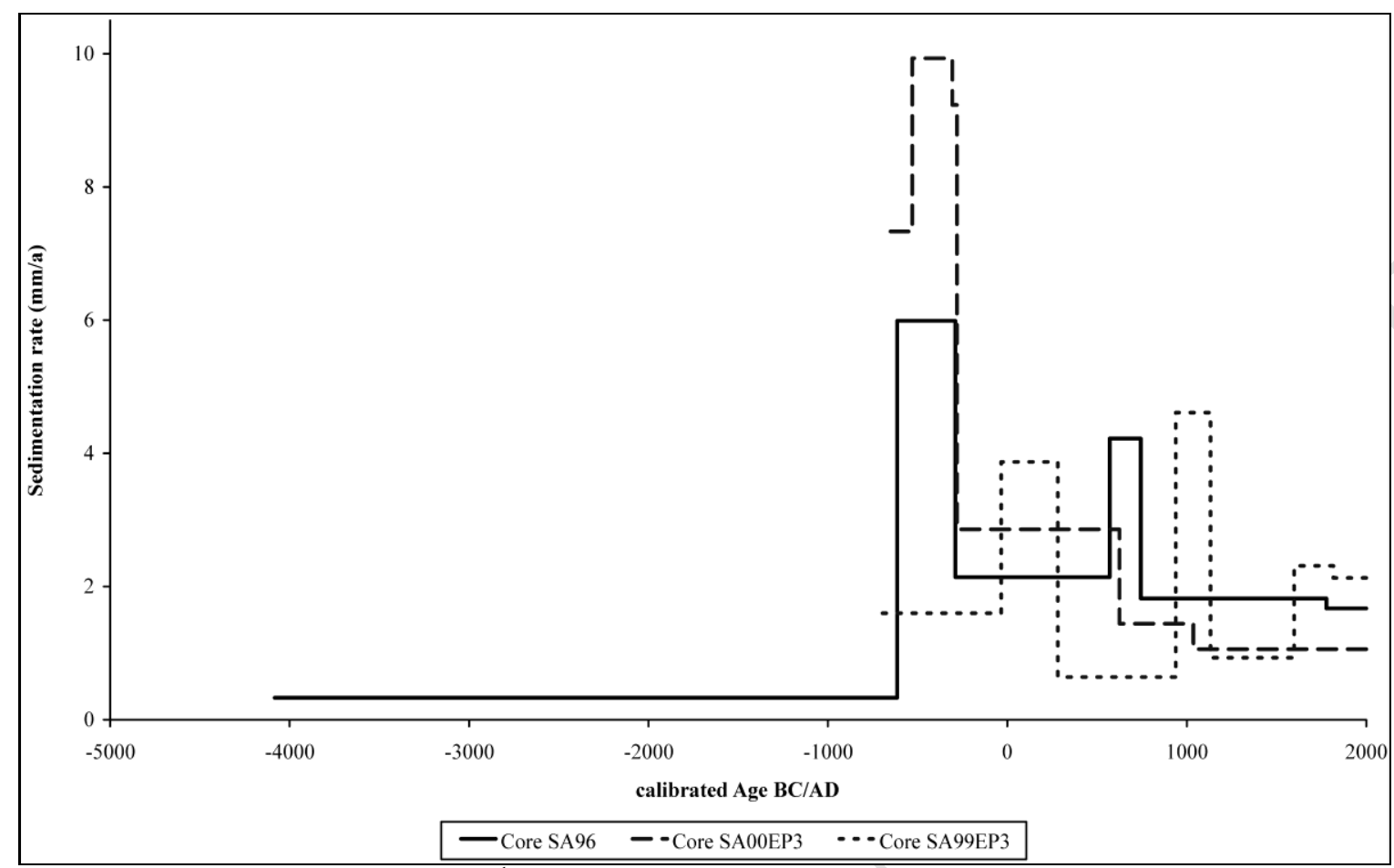

895 Fig. 4. Sedimentation rates $\left(\mathrm{mm} \mathrm{a}^{-1}\right)$ for 3 cores in the Gravgaz valley. The cores are ranked by distance to the karstic basin outlet (far: black; close: grey). 


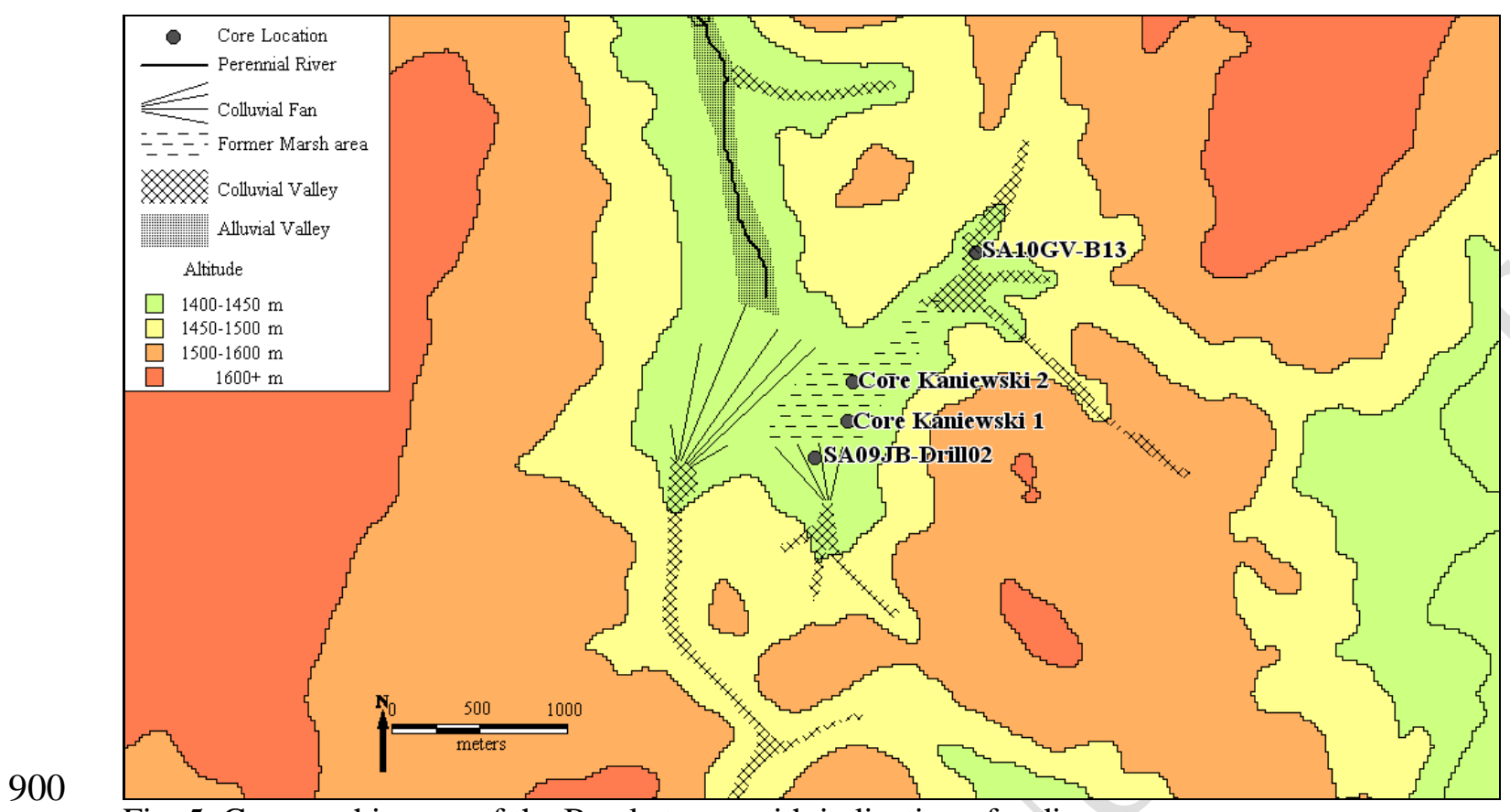

Fig. 5. Geomorphic map of the Bereket area with indication of sediment cores. 


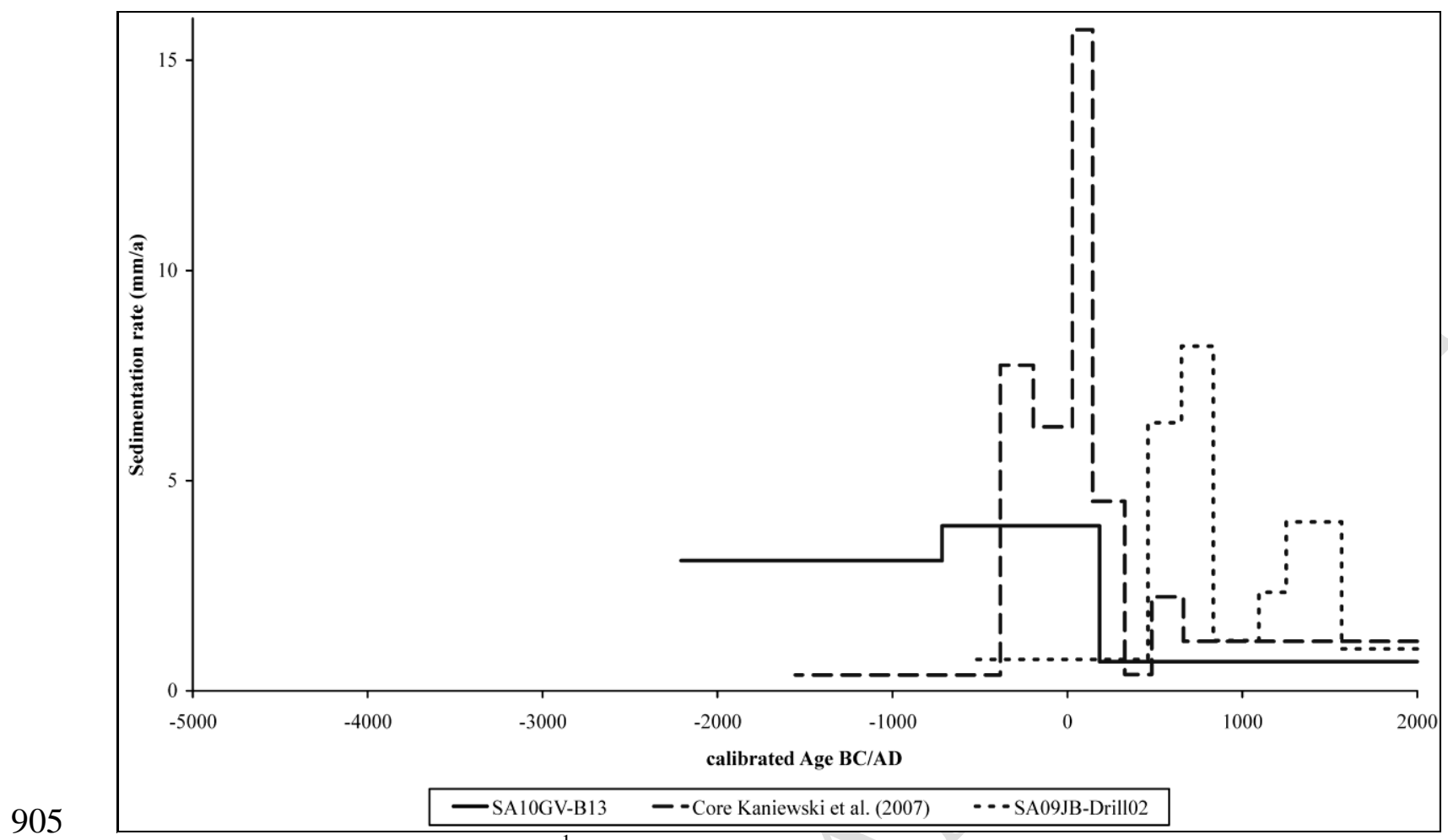

Fig. 6. Sedimentation rates $\left(\mathrm{mm} \mathrm{a}^{-1}\right)$ for three cores in the Bereket valley. The cores are sorted by upstream area size (small: full line; medium: broken line; large: dotted line). The core labelled 'Kaniewski' is a synthetic record based cores BKT1 and BKT2 (Fig. 5) that were integrated based on correspondence in the pollen records (Kaniewski et al, 2007a). 


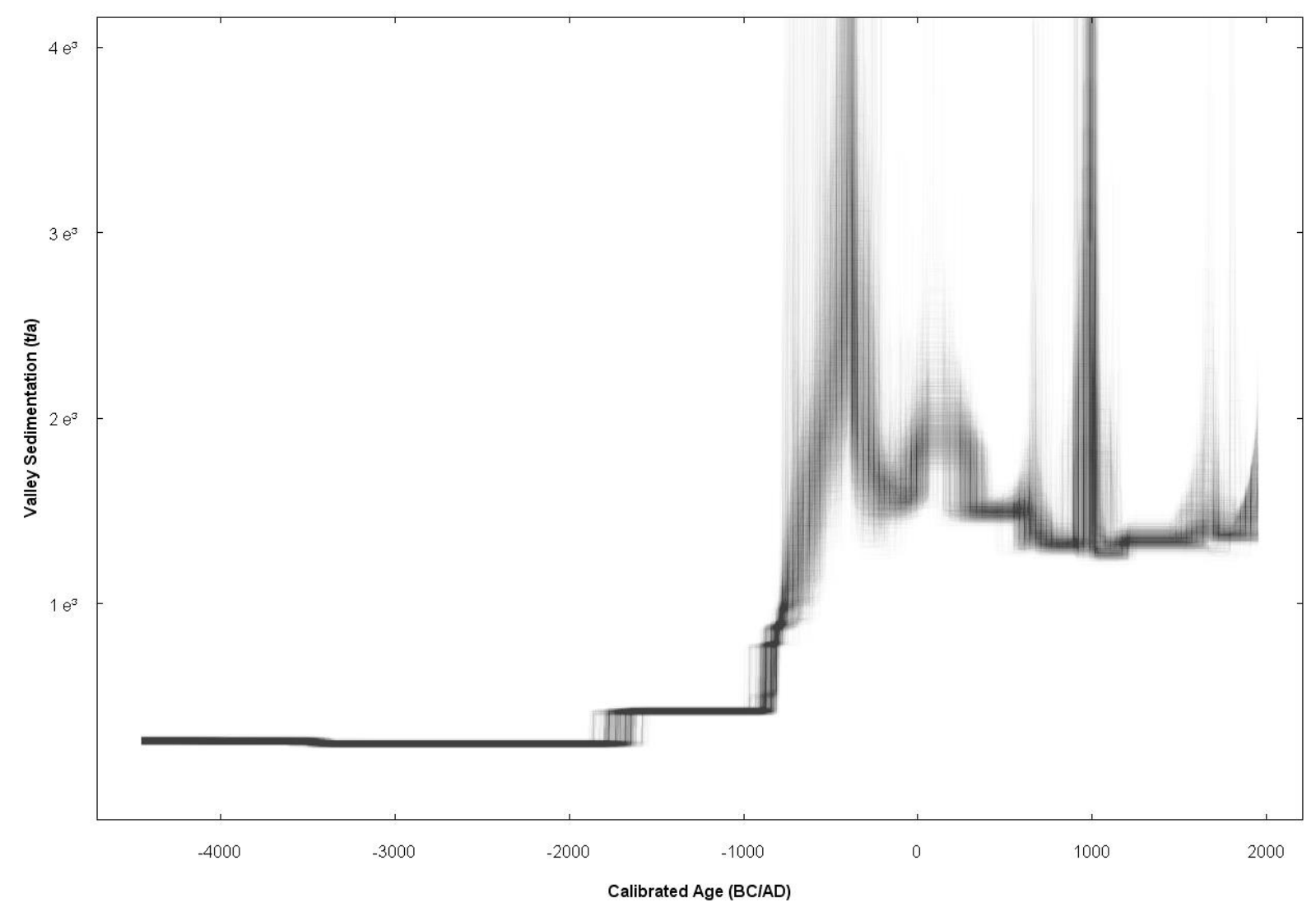

915 Fig. 7. Average valley sedimentation mass $\left(\mathrm{t} \mathrm{a}^{-1}\right)$ in the Gravgaz valley. This graph is the result of 2000 Monte Carlo simulations to account for the uncertainty on the calibrated radiocarbon ages. 


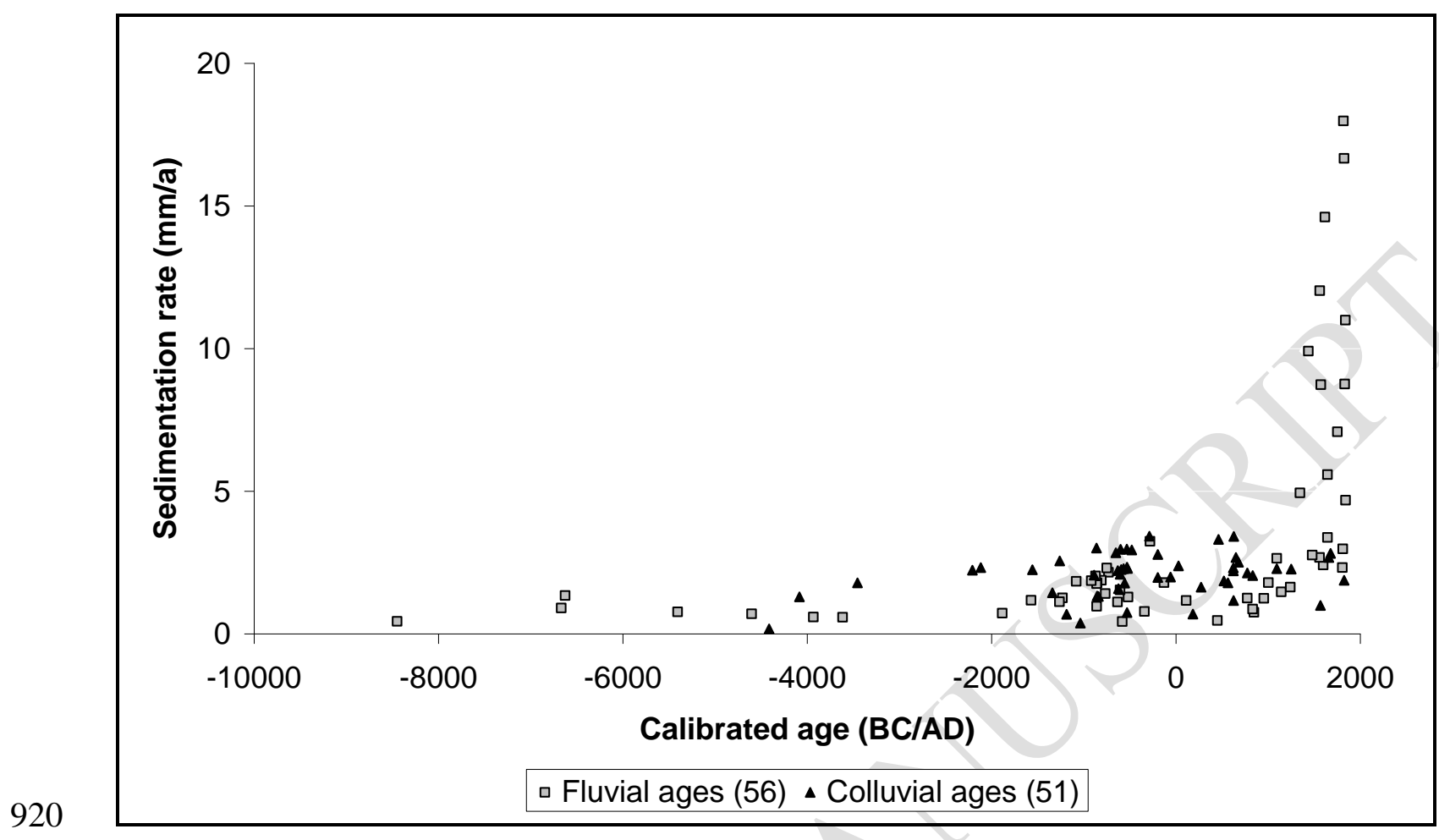

Fig. 8. Mean sedimentation rates (MSR, $\mathrm{mm} \mathrm{a}^{-1}$ ) for all dated samples, sorted per depositional environment. 


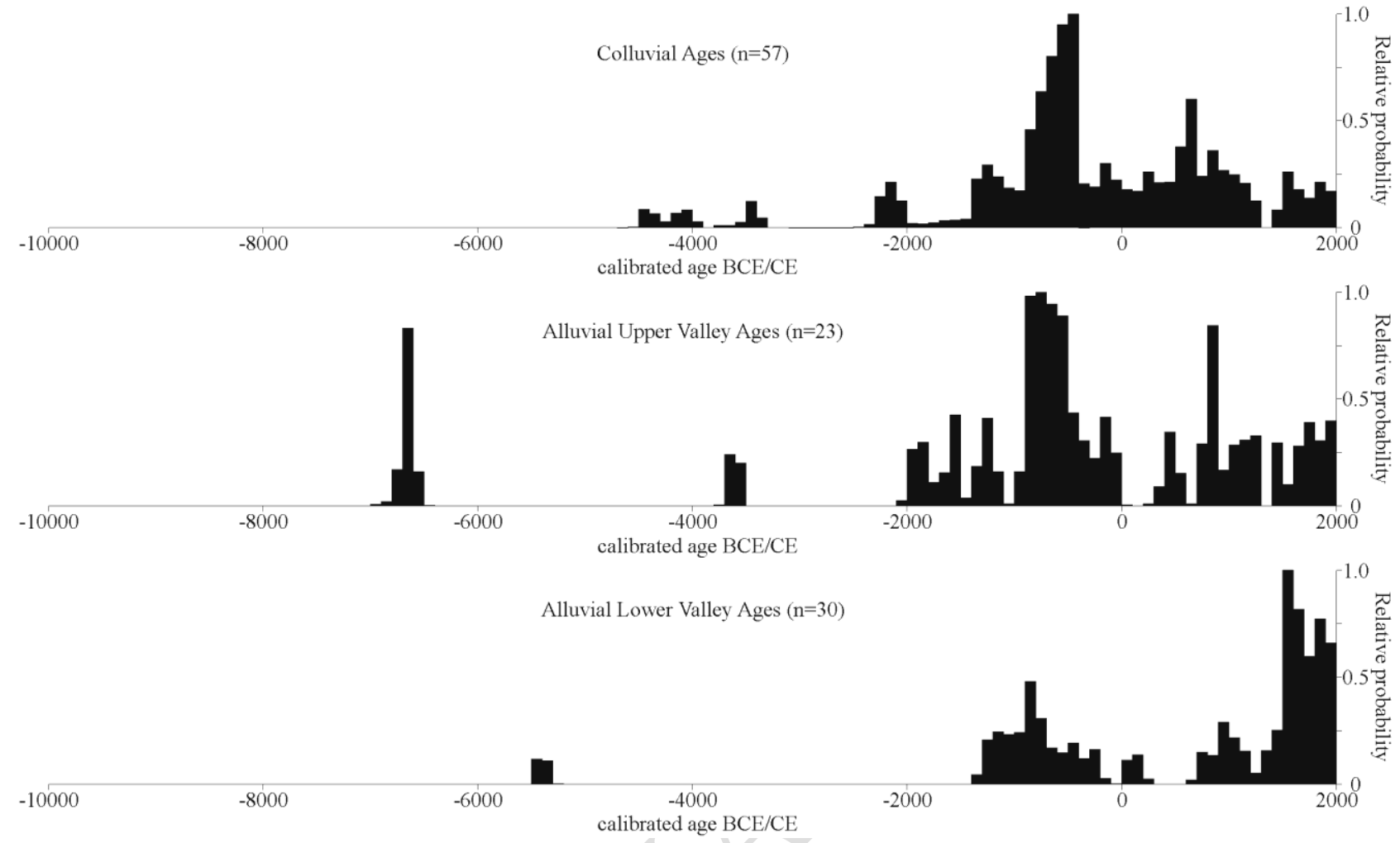

Fig. 9. Cumulative probability distributions (CPDs) for radiocarbon data in the territory of Sagalassos.

Probabilities were divided by the probabilities of equally spaced ages. Furthermore, the relative

probability was averaged per 100 year time period. (A) Colluvial ages $(n=57)(B)$ Alluvial upper valley ages $(n=23)(C)$ Alluvial lower valley ages $(n=30)$. 


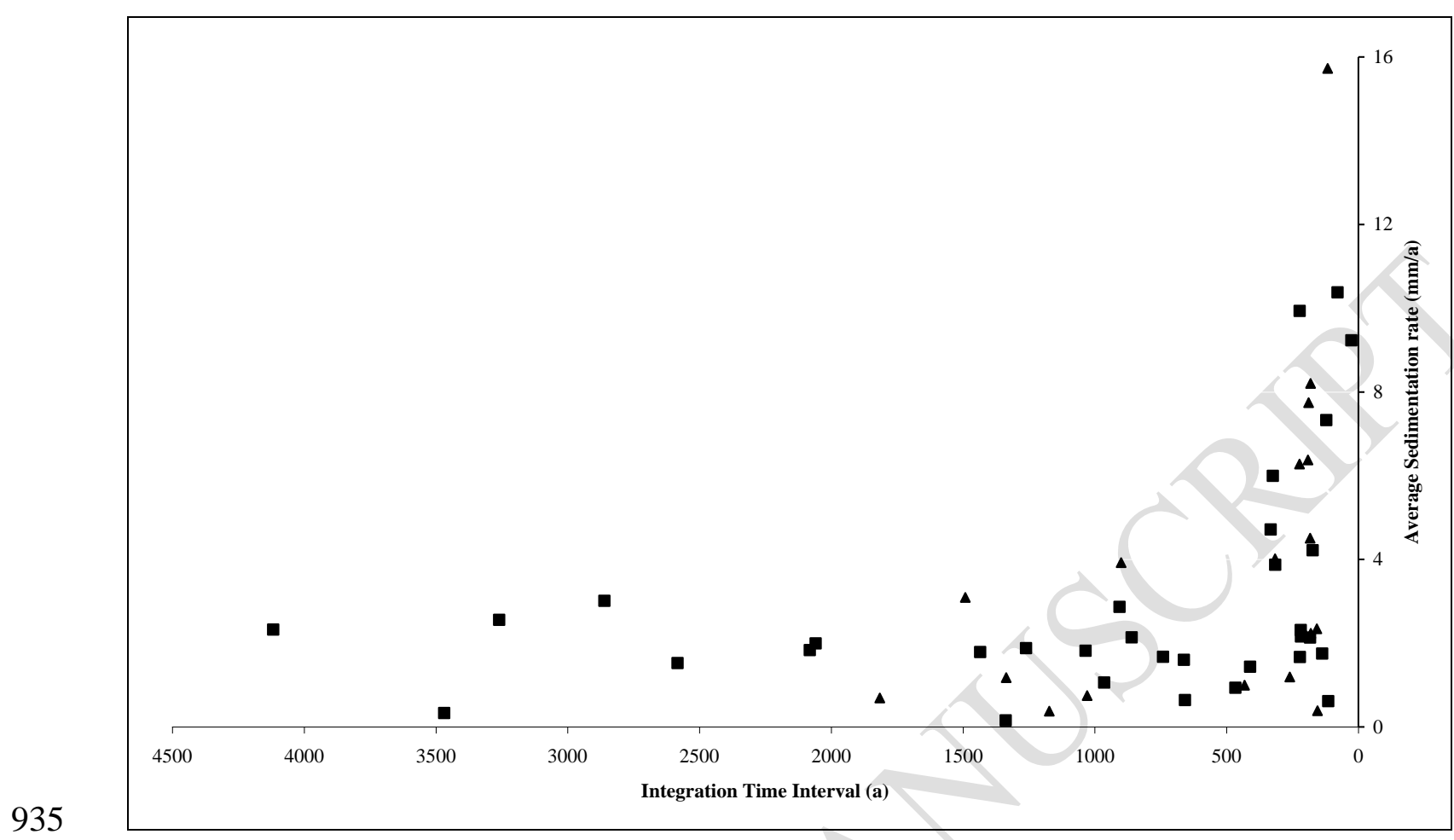

Fig. 10. Sedimentation rate $\left(\mathrm{mm} \mathrm{a}^{-1}\right)$ versus integrated time period (a) for all radiocarbon dated samples retrieved from the Gravgaz basin (squares) and from the Bereket basin (triangles). 


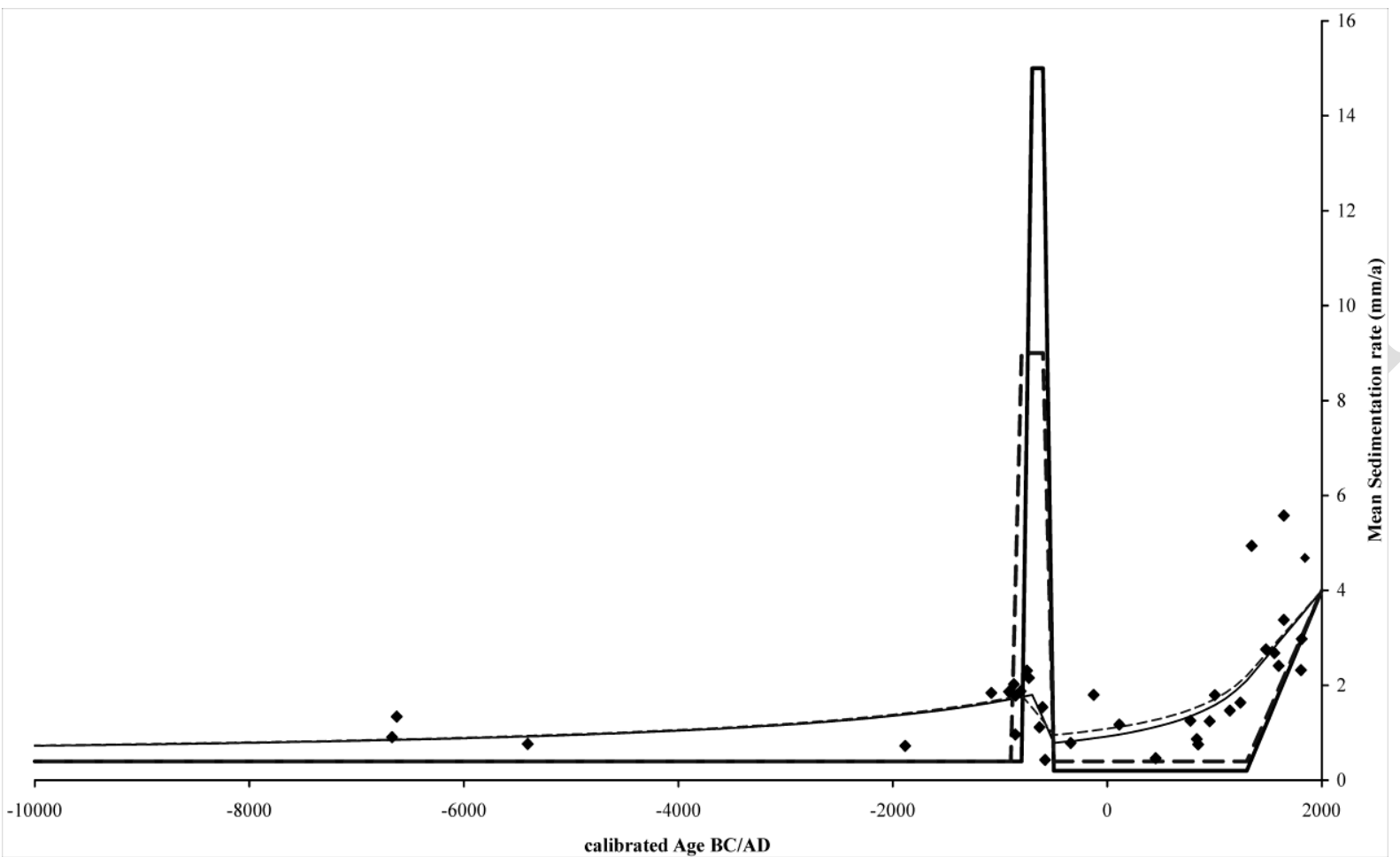

Fig. 11. Mean sedimentation rates $\left(\mathrm{SR}_{\mathrm{m}}\right)$ of chronometric data from alluvial overbank deposits in the Sagalassos territory (black dots) and two of the top 20 model results from the mean sedimentation rate $\left(\mathrm{SR}_{\mathrm{m}}\right)$ modelling approach on alluvial overbank ages. The black lines represent the optimal scenario $945(\mathrm{ME}=0.566)$, while the broken lines represent an alternative scenario with a slightly longer, but less intense sedimentation peak during the early $1^{\text {st }}$ millennium $\mathrm{BC}(\mathrm{ME}=0.563)$. These scenarios were selected to depict the variability between the best model runs based on ME. The black dots represent the data used to test the model. All points correspond to clear alluvial overbank deposits not disturbed by man. 


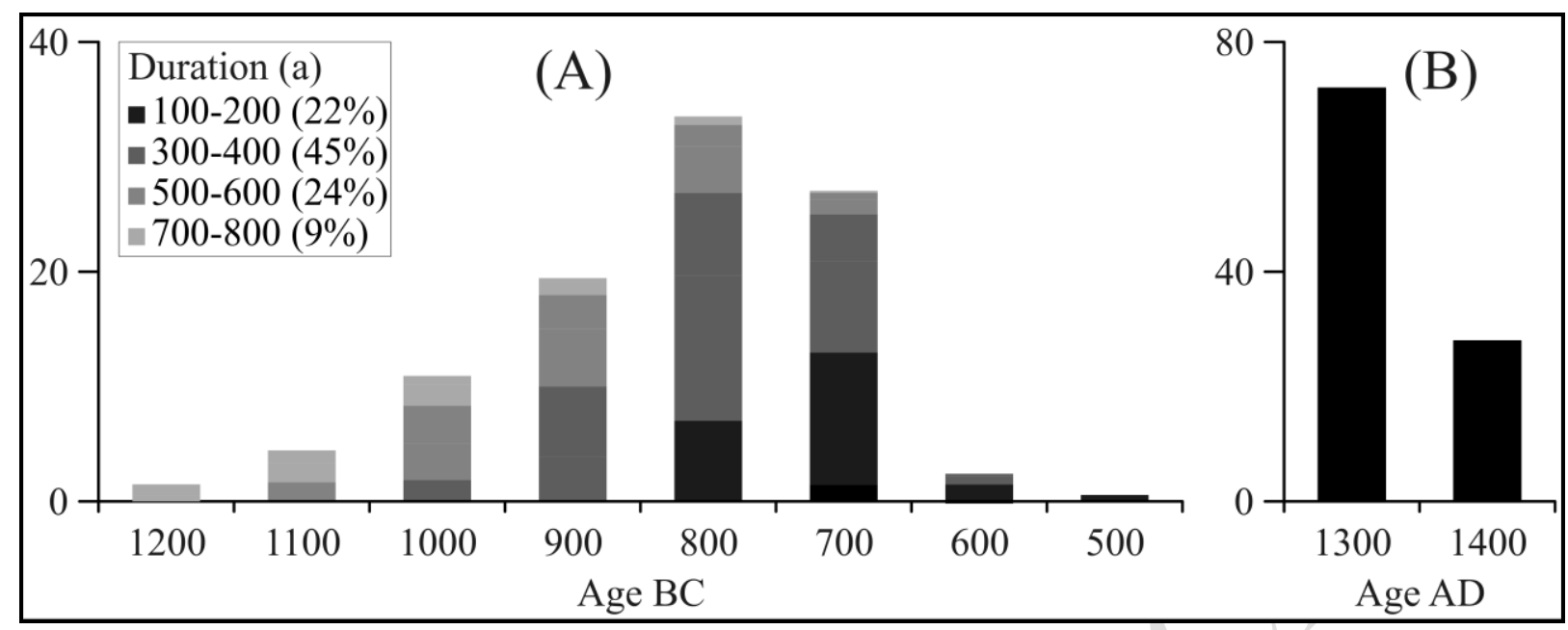

Fig. 12. Histograms of the $1 \%$ best mean sedimentation models based on model efficiency (ME) for 955 alluvial overbank sedimentation in the territory of Sagalassos. Bars are centred at the period assumed for the start of increased sedimentation; bar fill is chosen according to the assumed duration of the enhanced sedimentation period. (A) Start and duration of the increased sedimentation period during the $1^{\text {st }}$ millennium BC. (B) Start of the most recent phase of increased sedimentation. 


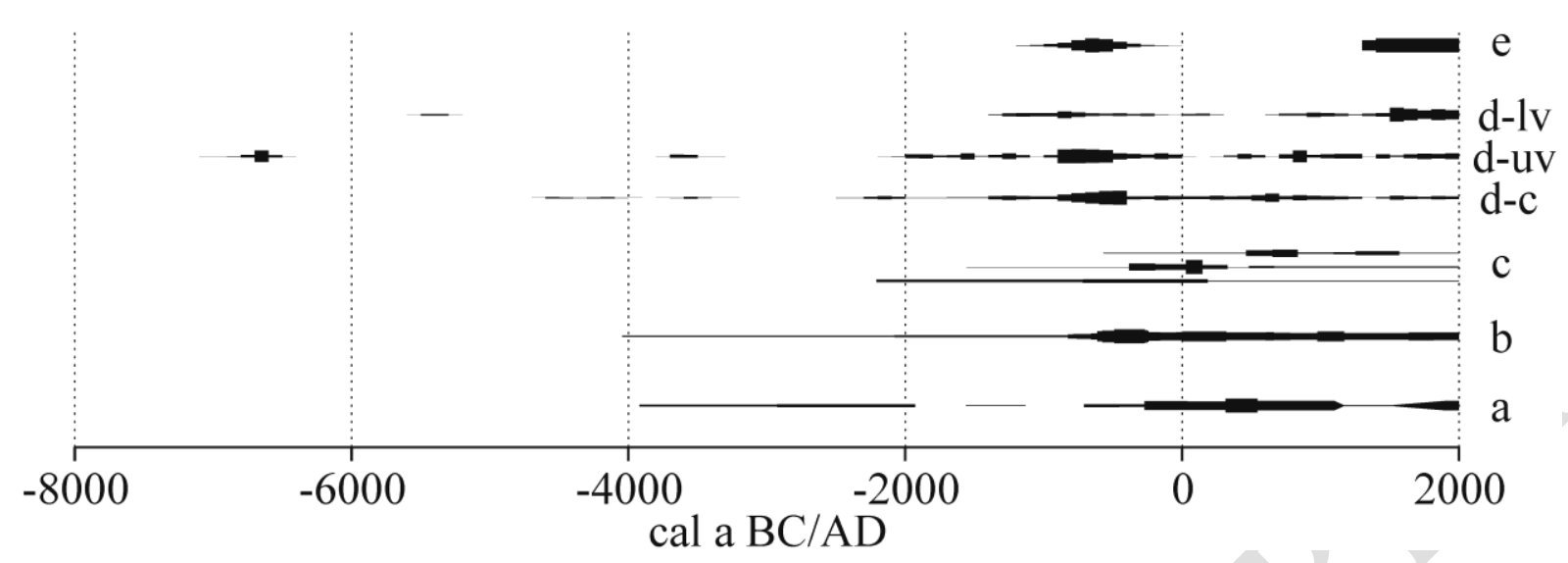

Fig. 13. Synthesis of the chronological information analyzed in this study, compared to the settlement density in the territory of Sagalassos. The line thickness is related to the number of settlements, sedimentation rate and cumulative probability value, respectively. (a) Number of settlements in the $\pm 1000 \mathrm{~km}^{2}$ territory of Sagalassos (Fig. 2). (b) Valley sedimentation in the Gravgaz valley bottom (Fig. 7). (c) Sedimentation rates in the three cores analyzed in the Bereket basin (Fig. 6). (d) Cumulative Probability Distribution values (Fig. 9): (d-c) colluvial deposits; (d-uv) upper river valley deposits; (d-lv) lower river valley deposits. (e) Results from the Monte Carlo modelling approach on mean sedimentation rates. 